\title{
A first approach to evaluate the vulnerability of islands' vertebrates to climate change in Mexico
}

\author{
Carolina URETA ${ }^{1}$, Angela P. CUERVO-ROBAYO ${ }^{2 *}$, Edith CALIXTO-PÉREZ ${ }^{3}$, \\ Constantino GONZÁLEZ-SALAZAR ${ }^{4}$ and Emiliano FUENTES-CONDE ${ }^{3}$
}

${ }^{1}$ Laboratorio de Genética Molecular, Desarrollo y Evolución de Plantas, Instituto de Ecología, Universidad Nacional Autónoma de México, 04510 Ciudad de México, México.

${ }^{2}$ Comisión Nacional para el Conocimiento y Uso de la Biodiversidad (CONABIO), Periférico-Insurgentes Sur 4903, 14010 Ciudad de México, México.

${ }^{3}$ Laboratorio de Análisis Espaciales, Instituto de Biología, Universidad Nacional Autónoma de México, 04510 Ciudad de México, México.

${ }^{4}$ Departamento de Ciencias Ambientales, Universidad Autónoma Metropolitana, Unidad Lerma, Hidalgo Pte. 46, 52006 Lerma, Estado de México, México.

*Corresponding author; email: ancuervo@gmail.com

Received: March 31, 2017; accepted: April 18, 2018

\begin{abstract}
RESUMEN
Las islas mexicanas son de los territorios más diversos del mundo y por lo tanto su conservación debería ser una prioridad nacional e internacional. Se han detectado tres amenazas principales para la conservación de la diversidad en las islas de México: especies invasoras, cambio de uso de suelo y cambio climático. La mayoría de los estudios se ha enfocado a evaluar con diferentes perspectivas la problemática de las especies invasoras, en tanto que otros han abordado como tema principal el cambio de uso de suelo. Sin embargo, este estudio es el primer intento de realizar una evaluación del impacto del cambio climático sobre las especies de las islas mexicanas. En este trabajo se tuvieron dos objetivos: generar una lista de especies registradas en islas y modelar el posible impacto del cambio climático sobre la distribución potencial de las especies. Para la modelación de los posibles impactos se utilizaron modelos de nicho ecológico. Esta herramienta se basa en relacionar puntos de presencias con variables ambientales con el fin de crear un perfil bioclimático que pueda proyectarse en otros tiempos y espacios geográficos. Se compiló información y se creó una nueva lista de especies en islas que duplica la cantidad que había registrado el gobierno mexicano; además, se realizó el modelado de nicho ecológico para 54 especies de vertebrados. El esfuerzo de compilación sobre especies de islas es un paso fundamental para su posterior conservación. En el caso del modelado de nicho ecológico, se decidió modelar especies de mamíferos, reptiles y anfibios. De estos tres grupos, los reptiles exhibieron mayores pérdidas y presentan el mayor número en la lista de especies más vulnerables. Si se considera un escenario sin dispersión, todas las especies evaluadas tienen pérdidas en sus áreas de distribución potencial a futuro. Sin embargo, si se toma en cuenta el escenario de dispersión total, el valor neto de cambio es positivo para la mayoría de las especies. En otras palabras, si no existen barreras humanas y la capacidad de dispersión es adecuada, es posible que el cambio en las condiciones climáticas no sea la amenaza principal para las especies residentes en islas. Al menos no en términos climáticos, pero habría que evaluar el papel que juega el incremento en el nivel del mar. No obstante, estas barreras ambientales y humanas existen en la mayoría de las especies evaluadas. Por otro lado, los mapas de riqueza muestran cambios futuros, ya que las áreas de mayor riqueza se desplazan al este y al norte. Finalmente, se encontraron diferencias significativas entre tiempos y escenarios en cuanto a pérdidas. Las mayores pérdidas se encontraron a largo plazo en el RCP $8.5 \mathrm{Wm}^{-2}$ en comparación del RCP $4.5 \mathrm{Wm}^{-2}$. Este resultado es relevante porque muestra que el rumbo que decida tomar la humanidad en términos de cambio climático tendrá impactos sobre la biodiversidad de las islas. Finalmente, recomendamos que futuros esfuerzos para evaluar vulnerabilidad al cambio climático
\end{abstract}


incorporen el aumento en el nivel del mar, cuyas consecuencias esperadas sobre las especies de islas serán mucho más graves.

\section{ABSTRACT}

Mexican islands are one of the most diverse territories in the world and consequently their conservation should be a national and international priority. Three main threats to islands' diversity have been detected: invasive species, land use change and climate change. Most studies have been focused on invasive species and land use change. Actually, as far as we know, this work is the first approach to evaluate climate change impacts on the biodiversity of islands in Mexico. We had two main goals: to list the vertebrate species that have been registered in Mexican islands and to model the possible impacts of climate change in the distribution of islands' vertebrates. To evaluate climate change impacts, we used the ecological niche modeling that relates geographic occurrences with environmental variables to create a bioclimatic profile that can be projected in other time and other geographic areas. In our results we obtained a list of species registered in Mexican islands that increased in more than twice the number of species acknowledged by the Mexican government and the ecological niche modeling of 54 vertebrate species. We found that the species list effort was very important, because knowing which species exist is the first step to preserve them. In terms of ecological niche modeling, we modeled mammals, reptiles and amphibians. From these three groups, reptiles were the group with greatest losses and more species in the top-ten vulnerable list. If we considered a no dispersion scenario, all evaluated species presented losses regarding their current potential distribution area. If the full dispersion scenario was taken into account, the net change value resulted positive for the majority of the species evaluated, consequently if no barriers exist and the dispersion ability is good enough, changes in climatic conditions might not be an important threat. However, this is not the case for most species evaluated. Areas with a higher number of species (richest areas) do show changes in the future with shifts to the east and north of the country. Finally, we could find significant differences between times and scenarios in terms of suitable area losses. Greatest losses can be found in the long term RCP $8.5 \mathrm{Wm}^{-2}$ in comparison to the long term RCP $4.5 \mathrm{Wm}^{-2}$, meaning that the direction that humanity takes in terms of climate change will have consequences on island biodiversity. In this work, we did not take into account the sea level rise, which is expected to have important impacts on islands species.

Keywords: Climate change, island's biodiversity, ecological niche modeling

\section{Introduction}

Mexico has around 3210 islands (INEGI, 2014) embracing at least 2000 terrestrial species with over $10 \%$ of endemism (Aguirre-Muñoz et al., 2010). Most Mexican islands are in the Pacific Ocean and the Gulf of California, but there are others all over the territory incorporating an important amount of climatic diversity that goes from very dry to very humid climates. In terms of biodiversity, these territories are considered some of the richest on Earth (Aguirre-Muñoz et al., 2010). Due to the biological importance of Mexican islands, their species conservation should be a national and international priority; however, there is still a lack of biological and ecological knowledge about these systems.

There are three main factors threatening Mexican islands' species: exotic species, land-use change and climate change (Aguirre-Muñoz et al., 2008, 2010). Efforts have mainly been focused on issues related to exotic species and land-use change (Arnaud et al.,
1993; Donlan et al., 2003; Knowlton et al., 2007), but very little attention has been given to climate change. Due to the lack of knowledge about island's biodiversity and climate change we propose the use of ecological niche modeling (ENM) as a first approach to evaluate the vulnerability of terrestrial vertebrates that have been registered in Mexican islands, although they are mostly not endemic to them.

Species vulnerability to climate change has commonly been assessed with ENM, which relates species occurrence with environmental variables to create an optimum bioclimatic profile that can be projected into geographic space and in different time frames (Peterson, 2011). With this analytical tool, it is possible to measure the exposure of species to climate change by projecting their potential geographic distribution under different general circulation models (GCM) (IPCC, 2014), revealing how changes in climatic conditions will affect the species current distribution (persist, increase, disappear or shift) (Pereira et al., 2010). 
We are aware that there are other factors rather than the lack of a climatically suitable geographic area that might increase islands' species vulnerability to climate change, such as specific biological characteristics (Foden et al., 2009, 2013a) and the sea level rise. However, this study is a first approach expected to help understanding how changes in climate will impact the potential distribution of islands' species. Our research had two main goals: (1) to create a presence species list of terrestrial vertebrates (birds, mammals, reptiles and amphibians) for knowing what has been registered until now in all Mexican islands, and (2) to assess ecological niche models of 54 terrestrial vertebrates species (mammals, reptiles and amphibians) (CONABIO 2011, 2013; Lee, 2000; Navarro and Gordillo, 2006; Ramírez, 1999; Wilson and Ruff, 1999) recorded in Mexican islands under future climate change projections. We decided to use a single way to refer to our vertebrate groups under study for three different reasons: (1) to make results more accessible to a broader public, like policymakers, (2) because our selected species were revised in the taxonomic authority catalogues published by the Comision Nacional para el Conocimiento y Uso de la Biodiversidad (National Commission for the Knowledge and Use of Biodiversity, CONABIO) (CONABIO, 2011, 2013; Navarro and Gordillo, 2006; Ramírez, 1999) where a common way of classification is used, and (3) the taxonomic discussion of these groups is beyond the goals of our study and does not affect our results. However, we are aware of the fact that there is a more accurate way of referring to the vertebrate groups under study (Cubo et al., 2005).

\section{Methods}

\subsection{Species selection}

In order to decide which species were going to be evaluated, we firstly needed to have a list of the species that were distributed in Mexican islands. As a first approach, the Mexican government provided us a list of 259 terrestrial vertebrate species (CONABIO, 2016). Then, we made an additional review of species in reports, theses, books, and governmental programs; and we increased the species list up to more than double the number of species that was firstly given to us by the Comisión Nacional para el Conocimiento y
Uso de la Biodiversidad (CONABIO) (Table I, Appendix I). Finally, the geographic distribution of the listed species (Appendix I) was double-checked with polygons of known distributions from the red list of the International Union for Conservation of Nature (IUCN, 2017) and with taxonomic authority catalogs, in order to confirm their current taxonomic status and distribution on Mexican islands (CONABIO, 2011, 2013; Navarro and Gordillo, 2006; Ramírez, 1999).

Once we prepared the species list, we looked up for the species geographic records at CONABIO (2017) and the Global Biodiversity Information Facility (GBIF, 2017). The first criterion for choosing species to be modeled was the number of unique geographic records. A minimum amount of records to create reliable models is still under discussion, but some experts suggest at least five (Pearson et al., 2007). We decided to use a minimum threshold of 10 unique records in order to have enough data for creating and validating the model. The second criterion was to reduce uncertainty and error sources coming from scarce information and conceptual complexity, and although marine mammals and birds were listed in the occurrence data set, we decided not to consider them in the ecological niche modeling. As far as we know, there are no future marine layers for Mexico and as a result it is not possible to create ecological niche models (ENM) in the ocean. In terms of birds, most of islands' species with over 10 unique records are migratory and consequently they need to be modeled in a particular way.

The groups of vertebrates modeled were mammals, reptiles and amphibians. Only 14 species of amphibians had more than 10 unique geographic records, so we decided to model all of them. Regarding mammals and reptiles, once we separated the species with 10 unique records we randomly selected 20 species from each taxonomic group. The random sample had the goal of giving us the representativeness over the group integrating species with different current risk category, distribution (large vs. restricted) (see Appendix II), and other biological characteristics such as population status and dispersal ability (even though this information is not available for most species). The aim was getting an insight of how the groups will be impacted in general by climate change conditions. The list of evaluated species is given in Appendix II. 
Table I. Top 10 evaluated species with greatest losses of future potential distribution area. (a) RCP $4.5 \mathrm{Wm}^{-2}$ (loss), (b) RCP $8.5 \mathrm{Wm}^{-2}$ (loss), (c) RCP $4.5 \mathrm{Wm}^{-2}$ (net change) and (d) RCP $8.5 \mathrm{Wm}^{-2}$ (net change).

\begin{tabular}{|c|c|c|c|c|c|}
\hline \multicolumn{6}{|c|}{ (a) $\mathrm{RCP} 4.5 \mathrm{Wm}^{-2}$} \\
\hline \multicolumn{3}{|c|}{2030} & \multicolumn{3}{|c|}{2050} \\
\hline Class & Species & Loss $(\%)$ & Class & Species & Loss $(\%)$ \\
\hline Reptile & Petrosaurus thalassinus & 79.834 & Reptile & Petrosaurus thalassinus & 81.684 \\
\hline Reptile & Phyllodactylus homolepidurus & 75.256 & Reptile & Phyllodactylus homolepidurus & 65.720 \\
\hline Bird & Pandion haliaetus & 70.457 & Reptile & Crotalus molossus & 48.223 \\
\hline Reptile & Crotalus molossus & 49.374 & Reptile & Lampropeltis zonata & 39.025 \\
\hline Reptile & Lampropeltis zonata & 37.019 & Reptile & Crotaphytus dickersonae & 33.306 \\
\hline Reptile & Crotaphytus dickersonae & 34.677 & Bird & Pandion haliaetus & 27.861 \\
\hline Reptile & Pituophis catenifer & 30.134 & Reptile & Pituophis catenifer & 27.758 \\
\hline Reptile & Phyllodactylus unctus & 28.496 & Amphibian & Incilius alvarius & 27.317 \\
\hline Bird & Sula nebouxii & 28.320 & Reptile & Mastigodryas melanolomus & 26.649 \\
\hline Amphibian & Incilius alvarius & 26.927 & Reptile & Phyllodactylus unctus & 26.477 \\
\hline
\end{tabular}

(b) $\mathrm{RCP} 8.5 \mathrm{Wm}^{-2}$

\begin{tabular}{lll|llc}
\hline \multicolumn{1}{c}{2030} & \multicolumn{3}{c}{2050} \\
\multicolumn{1}{c}{ Class } & \multicolumn{1}{c}{ Species } & Loss (\%) & \multicolumn{1}{c}{ Class } & \multicolumn{1}{c}{ Species } & Loss $(\%)$ \\
\hline Reptile & Petrosaurus thalassinus & 77.157 & Reptile & Phyllodactylus homolepidurus & 98.216 \\
Bird & Pandion haliaetus & 75.868 & Mammal & Peromyscus eva & 88.654 \\
Reptile & Phyllodactylus homolepidurus & 71.525 & Reptile & Crotalus molossus & 76.081 \\
Reptile & Crotalus molossus & 62.389 & Bird & Chadrarius nivosus & 75.711 \\
Reptile & Phyllodactylus xanti & 60.739 & Reptile & Petrosaurus thalassinus & 74.011 \\
Reptile & Lampropeltis zonata & 57.079 & Amphibian & Aneides lugubris & 68.45 \\
Reptile & Drymarchon corais & 47.568 & Reptile & Drymarchon corais & 64.498 \\
Reptile & Mastigodryas melanolomus & 47.441 & Reptile & Lampropeltis zonata & 63.891 \\
Reptile & Phyllodactylus unctus & 45.199 & Reptile & Ctenosaura hemilopha & 57.085 \\
Reptile & Pituophis catenifer & 44.317 & Mammal & Chaetodipus baileyi & 52.650 \\
\hline
\end{tabular}

(c) $\mathrm{RCP} 4.5 \mathrm{Wm}^{-2}$

\begin{tabular}{llc|llc}
\hline \multicolumn{2}{c|}{2030} & & \multicolumn{3}{c}{2050} \\
\hline Class & Species & Net Change & Class & Species & Net Change \\
\hline Reptile & Crotalus molossus & -40.297 & Reptile & Crotalus molossus & -38.126 \\
Reptile & Mastigodryas melanolomus & -14.088 & Reptile & Mastigodryas melanolomus & -14.087 \\
Reptile & Lampropeltis zonata & -11.046 & Reptile & Lampropeltis zonata & -12.159 \\
Amphibian & Anaxyrus cognatus & -6.043 & Amphibian & Anaxyrus cognatus & -7.088 \\
Mammal & Chaetodipus baileyi & -3.515 & Amphibian & Aneides lugubris & -2.172 \\
Reptile & Oxybelis aeneus & -1.113 & Mammal & Chaetodipus baileyi & -1.274 \\
Mammal & Chaetodipus penicillatus & 1.356 & Amphibian & Batrachoseps major & 0.63 \\
Amphibian & Batrachoseps major & 1.525 & Reptile & Oxybelis aeneus & 0.765 \\
Amphibian & Aneides lugubris & 3.543 & Mammal & Chaetodipus penicillatus & 4.384 \\
Reptile & Petrosaurus thalassinus & 9.028 & Reptile & Petrosaurus thalassinus & 5.487 \\
\hline
\end{tabular}

Loss: percentage of the present area that will be lost due to future conditions; Net Change: difference between future area with suitable conditions and suitable area that will be lost in the future. 
Table I. Top 10 evaluated species with greatest losses of future potential distribution area. (a) RCP $4.5 \mathrm{Wm}^{-2}$ (loss), (b) RCP $8.5 \mathrm{Wm}^{-2}$ (loss), (c) RCP $4.5 \mathrm{Wm}^{-2}$ (net change) and (d) RCP $8.5 \mathrm{Wm}^{-2}$ (net change).

\begin{tabular}{|c|c|c|c|c|c|}
\hline \multicolumn{6}{|c|}{ (d) $\mathrm{RCP} 8.5 \mathrm{Wm}^{-2}$} \\
\hline \multicolumn{3}{|c|}{2030} & \multicolumn{3}{|c|}{2050} \\
\hline Class & Species & Net Change & Class & Species & Net Change \\
\hline Reptile & Crotalus molossus & -48.832 & Amphibian & Aneides lugubris & -67.495 \\
\hline Reptile & Lampropeltis zonata & -36.646 & Reptile & Crotalus molossus & -62.944 \\
\hline Reptile & Mastigodryas melanolomus & -34.532 & Reptile & Lampropeltis zonata & -45.642 \\
\hline Amphibian & Aneides lugubris & -29.893 & Amphibian & Anaxyrus cognatus & -38.555 \\
\hline Reptile & Phyllodactylus xanti & -24.945 & Reptile & Mastigodryas melanolomus & -34.532 \\
\hline Amphibian & Anaxyrus cognatus & -17.541 & Reptile & Drymarchon corais & -30.285 \\
\hline Mammal & Chaetodipus baileyi & -14.670 & Amphibian & Batrachoseps major & -17.57 \\
\hline Reptile & Drymarchon corais & -4.446 & Mammal & Chaetodipus baileyi & -15.731 \\
\hline Amphibian & Batrachoseps major & -1.493 & Mammal & Lepus californicus & -5.341 \\
\hline Reptile & Oxybelis aeneus & 3.879 & Reptile & Ctenosaura hemilopha & 2.529 \\
\hline
\end{tabular}

Loss: percentage of the present area that will be lost due to future conditions; Net Change: difference between future area with suitable conditions and suitable area that will be lost in the future.

\subsection{Climate change scenarios}

The species ecological niche was modeled under a current climatic scenario (1961-2000) and two-time series (2015-2039 and 2075-2099) under two different representative concentration pathways (RCPs 4.5 and $8.5 \mathrm{Wm}^{-2}$ ) (IPCC, 2014) at a $1 \mathrm{~km}^{2}$ resolution, using regionalized climatology created with a weighted ensemble (Reliability Ensemble Averaging, REA) of 21 general circulation models (Fernández-Eguiarte et al., 2015). We modeled two contrasting RCPs scenarios to get an idea of the different outcome possibilities. The worst-case emission scenario is the RCP $8.5 \mathrm{Wm}^{-2}$, and it helps having an insight of the consequences under the greatest changes expected in climate. The moderate scenario, RCP $4.5 \mathrm{Wm}^{-2}$, gave us an insight of what would happen in terms of species geographic distribution if some positive actions take place to reduce future impacts.

To run ENMs we used 19 bioclimatic variables that represent annual tendencies and temporal variation of climatic values that can be related to more biological meaningful results (Nix, 1986). We generated these variables with the package "dismo" (Hijmans et al., 2014) of the open software R (R Core Team, 2014) and monthly values of precipitation, and maximum and minimum temperatures. The geographic area in which our species were projected was the entire Mexican territory $(M)$. The geographic area or $M$ in a $B A M$ diagram represents the reachable geographic area for the species, while $B$ are the biotic factors of the species niche and $A$ the abiotic factors (Soberón and Nakamura, 2009).

To select the geographic area $M$ we should consider which $B A M$ diagram is more plausible for our species. The main assumption for species distribution models using climatic change scenarios is that abiotic variables will be the main species constraints, and any reachable area for our target species cannot be occupied due to a lack of favorable environments. It would be a $B A M$ diagram in which $A$ is a subset of $M$ and $B$ is disregarded (Saupe et al., 2012). We considered the Mexican territory as the potential area to be occupied in a free dispersion scenario for all species $(M)$, and climatic conditions $(A)$ the principal species constraints to reach any region of Mexico ( $A$ is a ubset of $M$ ). We decided to include the entire Mexican territory, because even though we are modeling island species, most of them are not endemic to islands but are also distributed in the continent. Additionally, using a single $M$ for all evaluated species allowed us a fair comparison of loss or gain area under climate change conditions. In order to reduce collinearity between the climatic variables, we performed a Pearson correlation test and selected nine variables that were not related to each other (determination coefficient value threshold 
$\left.R^{2}=0.8\right)$ in the geographic area where models were projected $(M)$ (Soberón and Nakamura, 2009).

The following variables were used to create the model: Bio1: mean annual temperature; Bio2: mean diurnal range; Bio4: temporal variability; Bio6: minimum temperature of the coldest month; Bio7: annual range temperature; Bio12: annual precipitation; Bio13: precipitation of the wettest quarter; Bio18: precipitation of the hottest quarter, and Bio19: precipitation of the coldest quarter. This test was performed with the function cor in the R-based package (R Core Team, 2014).

\subsection{Modeling with BIOMOD}

The BIOMOD package (Thuiller et al., 2009) is a platform for ENM that works as a multimodeling system where several algorithms can be used simultaneously and helps creating different types of model ensembles (Thuiller et al., 2009). One of the uncertainties in climate change assessments is that projections of species distributions can vary between algorithms (Pearson et al., 2006). Ensembles are a way to manage and reduce uncertainty (Araújo and New, 2007). In this study we selected two algorithms: maximum entropy (MAXENT [Phillips et al., 2006]) and GAM (general additive models) that have shown a good performance in comparison to other methods (Elith et al., 2006). We used the default parameterization, creating randomly 10000 pseudo-absences and 10 replicates per algorithm. We split species records and used $70 \%$ to create the model and $30 \%$ to validate it. As a model assembly rule, we chose the total consensus, which was weighted by the sum of probabilities of the model through the true skill statistic value $(\mathrm{TSS}) \leq 0.7$, meaning that every model used for the ensemble had at least that validation value. The threshold for the binary maps (presence/absence) was also de maximization of the TSS. We chose the TSS test because it has been shown that it is the best statistical option to interpret binary maps dealing with ecological phenomena (Allouche et al., 2006). We also used the BIOMOD range change function to estimate the proportion and relative number of lost, gained and stable pixels for each time period and RCPs.

Only four out of 54 species evaluated had less than 20 records, one mammal and three reptiles (see
Appendix II); however, for species with less than 20 unique records a jackknife analysis was carried out. The jackknife method helps validating the predictability of models constructed with less than 20 data (Pearson et al., 2007). For species having more than 700 records, we used the SpThin packages (Aiello-Lammens et al., 2015). This library helps eliminating a specific amount of records to reduce bias resulting from oversampling and keeps the useful information in terms of unique records. It works by calculating the minimum geographic distance between two points and randomly eliminating the ones which distance is equal or shorter than this minimum distance, where thin.par $=10 \mathrm{~km}$.

\section{Results}

\subsection{Biodiversity in the islands of Mexico}

As we described above, we had to compile the information about vertebrates registered in Mexican islands. To our knowledge, this is the most complete list of Mexican vertebrate species with an insular distribution. Our list is made up of 87 mammals, 228 birds, 117 reptiles and 20 amphibians. From this list, that includes all terrestrial vertebrates (mammals, birds, reptiles and amphibians), there are 10 species not recognized by GBIF.org (2017) and other six that do not have any geographic record (Appendix I). Most bird species that have been registered in Mexican islands are migratory (Appendix I), which represents a more complex system to model (Pérez-Moreno et al., 2016); however, we encourage future assessments with a specific type of analysis.

\subsection{General tendencies in climate change vulnera- bility}

For each evaluated species we reported unique georeference data, the percentage of area loss in the future with respect to the area that is climatically suitable under current conditions, the percentage of new area that will have climatically suitable conditions under specific climate change scenarios in the future, and the net change, which is the difference between the future suitable area and the area loss (Appendix II). This information is presented for both RCPs 4.5 and $8.5 \mathrm{Wm}^{-2}$ and for both short- and long term time periods. If we assume that species will not have any 
kind of restriction to disperse and migrate (unlimited dispersion scenario), then it is possible to take into account the net change. However, for precaution in terms of conservation we cannot forget about the limited dispersion scenario, in which species are restricted by biological/ecological characteristics and anthropogenic barriers.

In general, all evaluated species from all groups presented climatically suitable areas that may be lost in both RCPs and time frames (Appendix II). Still, increases in suitability areas were in general higher than losses, meaning that in the future there will be more climatically suitable areas for most species. Significant statistical differences were observed between RCPs in terms of area loss, gain and net change at both time frames (Wilcoxon test, $\mathrm{P} \leq 0.05$ ). Significant differences were only found in the loss and gain of climatically suitable areas between scenarios 4.5 and $8.5 \mathrm{Wm}^{-2}$ in the long term (2075-2099) and in losses, gains and net change between times $\left(4.5 \mathrm{Wm}^{-2}\right.$ [2015-2039] vs. $4.5 \mathrm{Wm}^{-2}$ [2075-2099], and $8.5 \mathrm{Wm}^{-2}$ [2015-2039] vs. $8.5 \mathrm{Wm}^{-2}$ [2075-2099]).

To identify vulnerability between the studied groups, we created boxplots of the percentage of climatically suitable loss (Fig. 1) under a limited dispersion scenario. In this figure it is possible to distinguish that in both extremes analyzed, the "best case scenario" $\left(4.5 \mathrm{Wm}^{-2}\right)$ in the short term and "the worst-case emission scenario" in the long term $\left(8.5 \mathrm{Wm}^{-2}\right)$, reptiles are the species with greatest losses followed by amphibians and mammals. In the long term, the variability in area loss increases up to almost $100 \%$ of the area that is climatically suitable under current climatic conditions (Fig. 1).

\subsection{Top ten vulnerability list}

We ranked species and selected the top 10 with greatest losses under a limited dispersion scenario and the top 10 that will be more affected even when taking into account future suitable regions - i.e., unlimited dispersion scenario-(Table I). Under a limited dispersion scenario, reptiles are the group that has more species in the top 10 with greatest losses, followed by amphibians. Mammals are almost not present in the top 10 list (Table Ia, c). When net change is analyzed, reptiles continue to be a vulnerable group followed by amphibians and mammals. The current suitable area loss in these groups is so great that it cannot be compensated by future new areas with suitable conditions.

\subsection{Vulnerability inside the three vertebrate groups}

\subsubsection{Mammals}

In the short term (2015-2039), solely Chaetodipus baileyi will have a negative net change, which means that it will lose more climatically suitable area than it will win under both RCPs evaluated. The rest of the mammal species studied show a positive net change. Under the unlimited dispersion scenario at RCP $4.5 \mathrm{Wm}^{-2}, 80 \%$ of the species lose $10 \%$ of their distribution area. At RCP $8.5 \mathrm{Wm}^{-2}$, the percentage of species losing more than $10 \%$ of their distribution area rises to $90 \%$ (Appendix II).

In the long term, there are two species showing negative net change: Chaetodipus baileyi and Lepus californicus (only in RCP $8.5 \mathrm{Wm}^{-2}$ ). Under both RCPs, $90 \%$ of the species are expected to lose more than $10 \%$ of their distribution area. Greatest losses are expected from Chaetodipus baileyi (30\%) in RCP $4.5 \mathrm{Wm}^{-2}$ and from Peromyscus eva in RCP $8.5 \mathrm{Wm}^{-2}(88 \%)$.

\subsubsection{Reptiles}

In all times and scenarios, evaluated species lose a fraction of their suitable current area. Through time the percentage of area losses increases (Appendix II). In this group, more species are found with negative net change values. The species with greatest negative net change values are Lampropeltis zonata, Mastigodryas melanolomus and Crotalus molossus. Their net change value in the worst-case scenario (long term $\mathrm{RCP} 8.5 \mathrm{Wm}^{-2}$ ) rises to $-45.64,-34.53$ and $-62.94 \%$, respectively.

\subsubsection{Amphibians}

As with reptiles, amphibians had more than one species with negative net change values. In the short term, under RCP $4.5 \mathrm{Wm}^{-2}$, only Anaxyrus cognatus presented a net change of $-6.043 \%$, but under RCP $8.5 \mathrm{Wm}^{-2}$ there were two species Anaxyrus cognatus and Aneides lugubris (Appendix II). In the long term, Batrachoseps major had also a negative net change. Under an unlimited dispersion scenario, the two species that exhibited greatest losses did not have a negative net change because it was compensated with climatically new potential distribution areas. That is the case of Anaxyrus californicus and Incilius alvarius. 


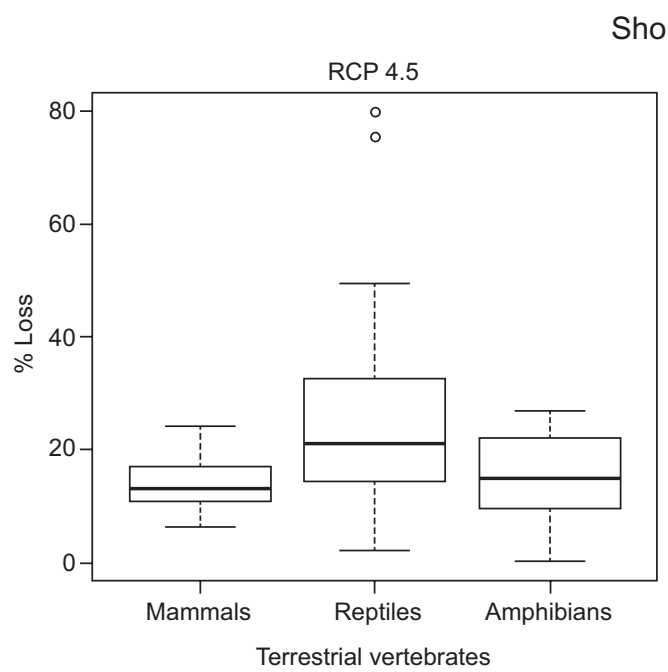

Short-Term

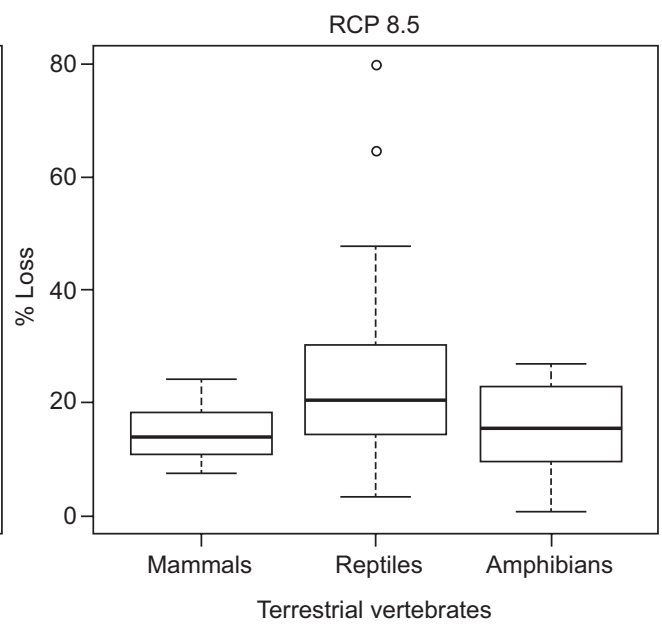

Long-Term
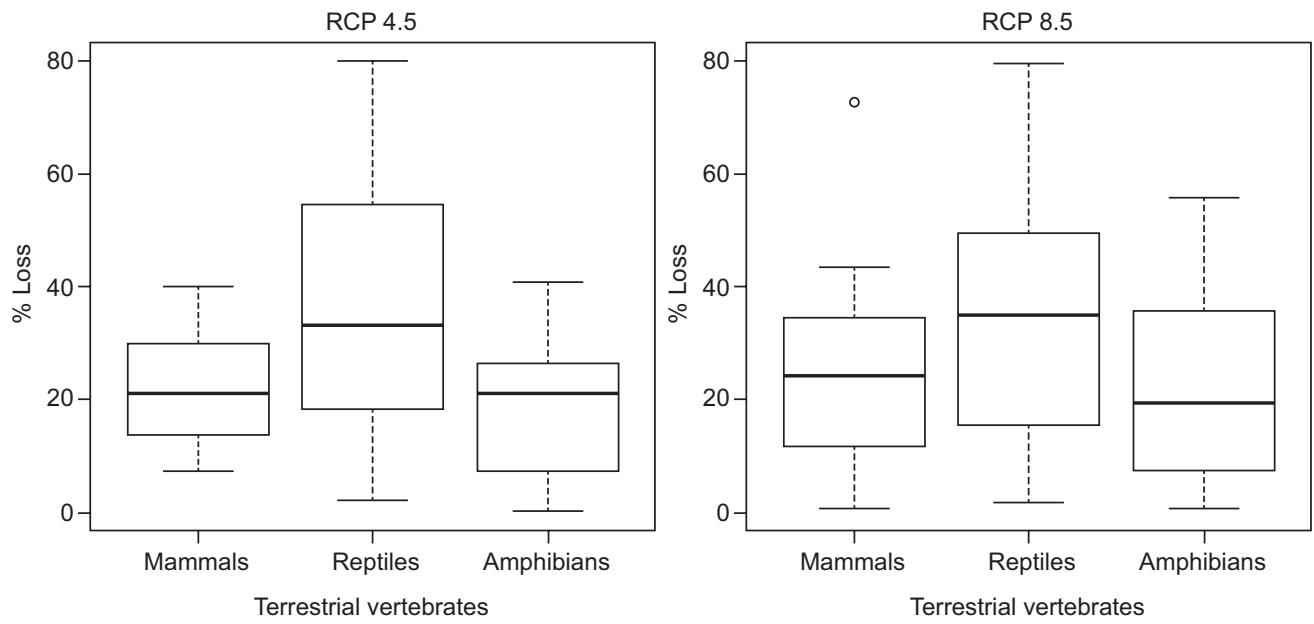

Fig. 1. Percentage of area loss in all evaluated groups in terms of species richness (number of species in a geographic area) for all taxonomic groups. The greatest species distributional shifts are shown in central and northern Mexico. Mammals' richest areas under current climatic conditions can be found in the Baja California peninsula. With time, the richest areas decrease and besides shifting towards the north, they show an eastward trend in colonization. For reptiles, the richest areas were found mainly in the coast of Baja California and Sonora, but under future scenarios the areas with higher number of species decrease and shift eastward toward the center of Mexico. A similar pattern can be found for amphibians (Appendix III).

\section{Discussion}

4.1 General tendencies in climate change vulnerability

This study is a good first approach to imrpove our knowledge on species diversity in Mexican islands and getting an insight of their vulnerability under climate change conditions. The compilation of species found in these islands allows us to understand that greater efforts are needed to increase our knowledge on which species are present in our territory. If this basic information is incomplete, it is very difficult to channel conservation efforts. Several species of different groups of vertebrates are present in Mexican islands but lack the minimum occurrence records (Appendix I). An increase in sampling efforts is needed for species mentioned in our appendix as 
"without records", which are 16 reptile species and two birds (Appendix I).

In terms of vulnerability to climate change, species that will suffer in the future great losses of their current climatically suitable area do not necessarily present a negative net change. Species might be gaining new potential distribution areas bigger than area losses. However, the fact that new climatically suitable areas will exist in the future does not mean that species will be able to reach them. There are factors such as dispersion ability and ecological or anthropogenic barriers that might keep species from relocating to the new suitable regions (Pearson and Dawson, 2003; Parmesan 2006). Consequently, it is important to keep in mind the question to be answered in order to decide which result is needed: the unlimited or the limited dispersion scenario. We think that in terms of conservation it will be important to use both results. Both scenarios can channel our efforts regarding conservation plans. For example, if ecological and anthropogenic barriers were obvious, then assuming that species will be able to reach new suitable areas would be unrealistic. Those species could be considered vulnerable even when its net change is positive. However, translocation could be an alternative. For species without new potential distribution areas, preservation efforts must take place in their current distribution area. In general, our results project positive net changes, meaning that new climatically suitable areas were greater than area losses for most species evaluated. We could also find significant differences in area losses between scenarios RCP 4.5 and RCP $8.5 \mathrm{Wm}^{-2}$ in the long term, meaning that if humanity chooses to follow an ecological way of life and reduces emissions, negative impacts in the distribution (and possible extinctions) of species will be significantly reduced. On the other hand, the richest areas for all evaluated taxonomic groups are expected to shift and change under future scenarios. In other words, hotspots of species richness will probably change and consequently current hotspots should not be the only tools used to concentrate conservation efforts.

In general, reptiles are the species with greatest losses and lower net change values (Fig. 1 and Table I). This result was very surprising, because amphibians as a group have been reported to be very vulnerable to environmental and climate changes
(Blaustein et al., 2003; Foden et al., 2013a). However, it is important to keep in mind that even when their net change or losses in the future are not greater than those of reptiles, most species in this group have very restricted distributions and other biological characteristics (such as the strong dependence to specific timing and amount of precipitation in order to fulfill their life history requirements) that make them sensitive to climate change (Wake, 2007).

\subsection{Vulnerability in the three vertebrate groups 4.2.1 Mammals}

Mammals were the group that showed less impact by climate change in their ranges. In fact, most species in this group had positive net change values (i.e., more area gains than losses). However, as mentioned above, positive net change does not necessarily mean less vulnerability. The mammals studied here are mainly distributed on the Pacific slope in the west side of the Sierra Madre Occidental pine-oak forest ecoregion (Wilson and Ruff, 1999; Ceballos and O1iva, 2005). Our outcomes show that some of the new suitable climate areas were forecasted toward eastern regions of Mexico that represent another ecoregion, and consequently an important ecological barrier for species to reach their new climatically suitable area. In addition, $65 \%$ of the species belong to the order Rodentia, for which low dispersion ability is recognized (Schloss et al., 2012). Thus, due to the rapidity of projected climatic changes, these species probably will not be able to modify their ranges fast enough to track suitable climates. On the other hand, some species may have better dispersion abilities but their ecological requirements restrict them to particular habitats; for instance, the piscivorous bat Myotis vivesi (González-Salazar et al., 2014) will not be able to occupy the predicted areas if these are not located near water bodies.

If we consider a limited dispersion scenario, i.e., species remain in areas where current ranges are retained more than colonizing new areas, mammals may suffer a reduction in their geographic distribution ranging from 6 to $24 \%$ in the short term for both RCPs. However, in the long term under RCP $8.5 \mathrm{Wm}^{-2}$, Peromycus eva and Chaetodipus arenarius showed 88 and $40 \%$ of area loss, respectively. These two species are endemic to the Baja California peninsula (Ceballos and Oliva, 2005), meaning that they should 
be considered highly threatened by climate change. Three other species, Ammospermophilus leucurus, Neotoma lepida and Peromyscus merriami, which are restricted to the Baja California peninsula even though they are not endemic to Mexico, show an area loss of $25-46 \%$. Therefore, in terms of mammals, this region can be considered at high risk of biodiversity loss. Similar results in the Baja California peninsula were identified by Aguado and Escalante (2015), who identified endemism in this area and showed reductions under climate change conditions.

\subsubsection{Reptiles}

In our results, reptiles were the group with greatest future losses in terms of potential distribution area (Fig.1, Table I). In general, populations of reptiles have been declining around the world (Gibbon et al., 2000), and species in Mexico are not the exception. The populations of several Mexican reptiles have been reduced or extinguished in the last $30 \mathrm{yrs}$ (Ballesteros-Barrera et al., 2007; Sinervo et al., 2010), mostly due to land used change.

In our study, under a limited dispersion scenario, most species will lose around $50 \%$ of their potential distribution. Nevertheless, even under the unlimited dispersion scenario, this group had a greater number of species with negative net change values. Within the species with negative net changes, $L$. zonata and $C$. molossus are currently considered as threatened by the Mexican government. L. zonata is a native species of Baja California, associated to water bodies and riparian vegetation, which are currently at risk due to fragmentation and extensive agriculture (Arriaga et al., 2000). C. molosus, is a generalist species that can be found in diverse types of vegetation; however, it is also threatened due to the presences of cattle and agriculture (Ramírez and Hernández, 2004). The reptile species with greatest losses, $P$. thalassius, is native of Baja California. It is currently under special protection by the Mexican authorities due to habitat degradation and fragmentation (Arriaga et al., 2000).

\subsubsection{Amphibians}

Amphibians were the second most vulnerable group according to our results. Three different species, A. cognatus, A. lugubris and B. major, presented negative net changes. A. lugubris and $B$. major have restricted distributions and are localized in the Baja California peninsula and its islands. By contrast, $A$. cognatus is widely distributed and its negative net change values might not represent an important threat to this species. The two species that exhibited greater losses but did not present negative net change values were $A$. californicus and I. alvarius, being A. californicus the only one with a very restricted distribution, which implies vulnerability to climate change. Even though climate change might not seem an important threat to this group, it is important to highlight that studies have shown in general that amphibians are vulnerable to changes in temperature and precipitation patterns (Wake, 2007; Foden et al., 2013b). Furthermore, greater threats are expected from the indirect impact of climate change, which will affect amphibians biological interactions increasing the probability of disease and the loss of positive interaction with specific tree species (Wake, 2007).

\section{Conclusions}

This study is an effort to increase our knowledge of Mexican islands' species. It was possible through this effort to have a better idea of the terrestrial vertebrate's diversity that exists in islands and for which species information is urgently needed. On the other hand, it was also an effort to increase our knowledge about the vulnerability of species to climate change. ENM was a first approach that allowed us to understand that climatically suitable areas will exist in the future for most species. Still, climate change cannot be discarded as an important threat, because we do not know if species will be able to migrate to new suitable areas. Furthermore, climate change might affect species in indirect ways by modifying their biological interactions with other organisms or simply because their biological characteristics make them vulnerable to any environmental change. Finally, sea level rise, which is expected to have great negative impacts on islands diversity (Bellard, 2013), was not considered in this study.

\section{Acknowledgments}

We would like to thank the Dirección General de Asuntos del Personal Académico (DGAPA) for the scholarship given to the first author, as well as 
the Instituto Nacional de Ecología y Cambio Climático and the Programa de las Naciones Unidas para el Desarrollo for their support to fulfill this project.

\section{References}

Aguado-Bautista Ó. and Escalante T., 2015. Cambios en los patrones de endemismo de los mamíferos terrestres de México por el calentamiento global. Rev. Mex. Biodivers. 86, 99-110.

DOI: $10.7550 / \mathrm{rmb} .46637$

Aguirre-Muñoz A., Croll D.A., Donlan C.J., Henry III R.W., Hermosillo M.A., Howald G.R., Keitt B. S., Luna-Mendonza L., Rodríguez-Malagón M. and Salas-Flores L.M., 2008. High-impact conservation: invasive mammal eradications from the islands of western Mexico. AMBIO 37, 101-107.

DOI: 10.1579/0044-7447(2008)37[101:HCIMEF]2.0. $\mathrm{CO} ; 2$

Aguirre-Muñoz A., Bezaury Creel J., De la Cueva H., March Mifust I. and Peters Recagno E. (Comp.), 2010. Islas de México, un recurso estratégico. Instituto Nacional de Ecología-The Nature Conservancy-Grupo de Ecología y Conservación de Islas- Centro de Investigación Científica y de Educación Superior de Ensenada, Mexico. Available at: http://www.biodiversidad.gob.mx/ecosistemas/pdf/IslasMex.pdf.

Aiello-Lammens M.E., Boria R., Radosavljevic A., Vilela B. and Anderson R.P., 2015. spThin: an R package for spatial thinning of species occurrence records for use in ecological niche models. Ecography 38, 541-545. DOI: $10.1111 /$ ecog.01132

Allouche O., Tsoar A. and Kadmon R., 2006. Assessing the accuracy of species distribution models: Prevalence, kappa and the true skill statistic (TSS). J. Appl. Ecol. 43, 1223-1232.

DOI: 10.1111/j.1365-2664.2006.01214.x

Araújo M.B. and New M., 2007. Ensemble forecasting of species distributions. Trends Ecol. Evol. 22, 42-27. DOI: $10.1016 /$ j.tree.2006.09.010

Arriaga L. Espinoza-Rodriguez J.M., Aguilar-Zuñiga C., Martinez-Romero E., Gomez-Mendoza L. and Loa Loza E., 2000. Regiones terrestres prioritarias de México. Comisión Nacional para el Conocimiento y Uso de la Biodiversidad. Disponible en: http://bioteca. biodiversidad.gob.mx/janium/Documentos/1036.pdf. Arnaud G., Rodríguez A., Ortega-Rubio A. and Álvarez-Cárdenas S., 1993. Predation by cats on the unique endemic lizard of Socorro Island (Urosaurus auriculatus), Revillagigedo, Mexico. Ohio J. Sci. 93, 101-104. Available at: http://hdl.handle.net/1811/23573.

Ballesteros-Barrera C., Martínez-Meyer E. and Gadsden H., 2007. Effects of land-cover transformation and climate change on the distribution of two microendemic lizards, genus Uma, of northern Mexico. J. Herpetology 41, 733-740. DOI: 10.1670/06-276.1

Bellard C., Leclerc C. and Courchamp F., 2013. Impact of sea level rise on the 10 insular biodiversity hotspots. Global Ecol. Biogeogr. 32, 203-2012.

DOI: $10.1111 /$ geb. 12093

Blaustein A.R., Romansic J.M., Kiesecker J.M. and Hatch A.C., 2003. Ultraviolet radiation, toxic chemicals and amphibian population declines. Divers. Distrib. 9, 123140. DOI: 10.1046/j.1472-4642.2003.00015.x

Ceballos G. and Oliva G., 2005. Los mamíferos silvestres de México. Comisión Nacional para el Conocimiento y Uso de la Biodiversidad-Fondo de Cultura Económica, México, 968 pp.

CONABIO, 2011. Catálogo de autoridades taxonómicas de los anfibios (Amphibia: Craniata) de México. Base de datos SNIB-CONABIO. Incluye información del proyecto CS003. Comisión Nacional para el Conocimiento y Uso de la Biodiversidad, México.

CONABIO, 2013. Catálogo de autoridades taxonómicas de los reptiles (Reptilia:Craniata) nativos de México. Base de datos SNIB-CONABIO. Incluye información del proyecto CS003. Comisión Nacional para el Conocimiento y Uso de la Biodiversidad, México.

CONABIO, 2016. Sistema Nacional de Información sobre Biodiversidad (SNIB). Registros de especímenes, versión 2016-09. Comisión Nacional para el Conocimiento y Uso de la Biodiversidad, México. Available at: http://www.snib.mx/d/CONABIO-SNIB-Version-201609.pdf.

Cubo J., Ponton F., Laurin M., De Margerie E. and Castanet J., 2005. Phylogenetic signal in bone microstructure of sauropsids. Syst. Biol. 54, 562-574.

DOI: $10.1080 / 10635150591003461$

Donlan C.J., Howald G.R., Tershy B.R. and Croll D.A., 2003. Evaluating alternative rodenticides for island conservation: roof rat eradication from the San Jorge Islands, Mexico. Biol Conserv114, 29-34.

DOI: 10.1016/S0006-3207(02)00401-9

Elith J., Graham C.H., Anderson R.P., Dudık M., Ferrier S., Guisan A., Hijmans R.J., Huettmann F., Leathwick J.R., Lehmann A., Li J., Lohmann L.G., Loiselle B.A., 
Manion G., Moritz C., Nakamura M., Nakazawa Y., Overton J., McC., Peterson A.T., Phillips S. J., Richardson K.S., Scachetti-Pereira R., Schapire R.E., Soberón J., Williams S., Wisz M. S. and Zimmermann N.E., 2006. Novel methods improve prediction of species' distributions from occurrence data. Ecography 29, 129-151. DOI: 10.1111/j.2006.0906-7590.04596.x

Fernández-Eguiarte A., Zavala Hidalgo J., Romero Centeno R., Conde Álvarez A.C. and Trejo Vázquez R.I., 2015. Actualización de los escenarios de cambio climático para estudios de impactos, vulnerabilidad y adaptación. Centro de Ciencias de la Atmósfera, Universidad Nacional Autónoma de México-Instituto Nacional de Ecología y Cambio Climático-Secretaría de Medio Ambiente y Recursos Naturales, México. Disponible en: http:// atlasclimatico.unam.mx/AECC/servmapas/.

Foden W., Mace G.M., Vié J.-C., Angulo A., Butchart S.H., DeVantier L., Dublin H.T., Gutsche A., Stuart S., and Turak E., 2009. Species susceptibility to climate change impacts. In: Wildlife in a changing world-an analysis of the 2008 IUCN Red List of threatened species (Vié J.-C., Hilton-Taylor C. and Stuart S.N., Eds.). International Union for Conservation of Nature, Gland, Switzerland, 77-88.

Foden W., Butchart S.H., Stuart S.N., Vié J.-C., Akçakaya H.R., Angulo A., DeVantier L.M., Gutsche A., Turak E. and Cao L., 2013a. Identifying the world's most climate change vulnerable species: A systematic trait-based assessment of all birds, amphibians and corals. PloS One 8, e65427. DOI: 10.1371/journal.pone.0065427

Foden W., Butchart S.H.M., Stuart S., Vié J.C., Akcakaya H.R., Angulo A., Devantier L., Gutsche A., Turak E., Cao L., Donner S., Katariya V., Bernard R., Holland R., Hughes A., O’Hanlon S., Garnett S., Sekercioglu C. and Mace G.M., 2013b. Identifying the world's most climate change vulnerable species: A systematic trait-based assessment of all birds, amphibians and corals. PloS One 8, e65427. DOI: 10.1371/journal. pone. 0065427

GBIF, 2017. Global Biodiversity Information Facility. Available at: https://www.gbif.org.

Gibbon J.W., Scott D.E., Ryan T.J., Buhlmann K.A., Tuberville T.D., Metts B.S., Greene J.L., Mills T., Leiden Y., and Poppy S., 2000. The global decline of reptiles, déjà vu amphibians: Reptile species are declining on a global scale. Six significant threats to reptile populations are habitat loss and degradation, introduced invasive species, environmental pollution, disease, unsustainable use, and global climate change. BioScience 50, 653-666.

DOI: $10.1641 / 0006-3568(2000) 050[0653: T G-$ DORD]2.0.CO;2

González-Salazar C., Martínez-Meyer E. and López-Santiago G., 2014. A hierarchical classification of trophic guilds for North American birds and mammals. Rev. Mex. Biodivers. 85, 931-941. DOI: 10.7550/rmb.38023

Hijmans R., Phillips S., Leathwick J. and Elith J., 2017. Package "dismo". R package. Available at: https:// cran.r-project.org/web/packages/dismo/dismo.pdf(last accessed on: June 2018).

INEGI, 2014. Catálogo del Territorio Insular Mexicano. Subgrupo del Catálogo de Islas Nacionales del Grupo Técnico para la Delimitación de las Zonas Marítimas Mexicanas, 2014. INEGI, SEGOB, SEMAR, SEMARNAT, SRE, SCT, INECC, CONANP, UNAM. Aguascalientes, Mexico, 245 pp. Available at: http:// internet.contenidos.inegi.org. $\mathrm{mx} /$ contenidos/productos/prod_serv/contenidos/espanol/bvinegi/productos/ nueva_estruc/702825079239.pdf

IPCC, 2014. Cambio climático 2014: Impactos, adaptación y vulnerabilidad. Resumen para responsables de políticas. Contribución del Grupo de trabajo II al Quinto Informe de Evaluación del Grupo Intergubernamental de Expertos sobre el Cambio Climático. Organización Meteorológica Mundial, Ginebra, Suiza, 34 pp.

IUCN, 2017. IUCN Red List of Threatened Species. Version 2013.2. International Union for Conservation of Nature and Natural Resources. Available at: http:// www.iucnredlist.org.

Knowlton J.L., Josh Donlan C., Roemer G.W., Samaniego-Herrera A., Keitt B.S., Wood B., Aguirre-Muñoz A., Faulkner K.R. and Tershy B.R., 2007. Eradication of non-native mammals and the status of insular mammals on the California Channel Islands, USA, and Pacific Baja California Peninsula Islands, Mexico. Southwest Nat. 52, 528-540.

DOI: 10.1894/0038-4909(2007)52[528:EONMAT]2.0. $\mathrm{CO} ; 2$

Lee J.C., 2000. A field guide to the amphibians and reptiles of the Maya world: the lowlands of Mexico, northern Guatemala, and Belize. Cornell University Press, 448 pp. Navarro S.A. and Gordillo A., 2006. Catálogo de autoridades taxonómicas de las Aves de México. Facultad de Ciencias, UNAM. Base de datos del Sistema Nacional de Información sobre Biodiversidad. Proyecto CS010. Comisión Nacional para el Conocimiento y Uso de 
la Biodiversidad, Mexico. Available at: http://www. biodiversidad.gob.mx/especies/gran_familia/animales/ aves/doc/Aves.pdf.

Nix H.A., 1986. A biogeographic analysis of Australian elapid snakes. In: Atlas of elapid snakes of Australia (Longmore R., Ed.). Australian Government Publishing Service, Camberra, 4-15.

Parmesan C., 2006. Ecological and evolutionary responses to recent climate change. Annu. Rev. Ecol. Evol. Syst. 37, 637-669.

DOI: 10.1146/annurev.ecolsys.37.091305.110100

Pearson R.G. and Dawson T.P., 2003. Predicting the impacts of climate change on the distribution of species: are bioclimate envelope models useful? Global Ecol. Biogeogr. 12, 361-371.

DOI: 10.1046/j.1466-822X.2003.00042.x

Pearson R.G., Raxworthy C.J., Nakamura M. and Peterson A.T., 2007. Predicting species distributions from small numbers of occurrence records: a test case using cryptic geckos in Madagascar. J. Biogeogr. 34,102-117.

DOI: $10.1111 /$ j.1365-2699.2006.01594.X

Pearson R.G., Thuiller W., Araújo M.B., Martinez-Meyer E., Brotons L., McClean C., Miles L., Segurado P., Dawson T.P. and Lees D.C., 2006. Model-based uncertainty in species range prediction. J. Biogeogr. 33, 1704-1711. DOI: 10.1111/j.1365-2699.2006.01460.x

Pereira H.M., Leadley P. W., Proença V., Alkemade R., Scharlemann J.P., Fernandez-Manjarrés J.F., Araújo M.B., Balvanera P., Biggs R. and Cheung W.W., 2010. Scenarios for global biodiversity in the 21 st century. Science 330, 1496-1501.

DOI: 10.1126/science.1196624

Pérez-Moreno H., Martínez-Meyer E., Soberón J. and Rojas-Soto O., 2016. Climatic patterns in the establishment of wintering areas by North American migratory birds. Ecol. Evol. 6, 2022-2033.

DOI: $10.1002 /$ ece 3.1973

Peterson A. T., Soberón J., Pearson R.G., Anderson R.P., Martínez-Meyer E., Nakamura M. and Araújo M.B., 2011. Ecological niches and geographic distributions. Princeton University Press, 328 pp. (Monographs in Population Biology, 49).

Phillips S.J., Anderson R.P. and Schapire R.E., 2006. Maximum entropy modeling of species geographic distributions. Ecol. Model. 190, 231-259.

DOI: 10.1016/j.ecolmodel.2005.03.026

Ramírez P.J., 1999. Catálogo de autoridades de los mamíferos terrestres de México. Universidad Autónoma
Metropolitana-Iztapalapa. Base de datos SNIB-Conabio, proyecto Q023, 111 pp. Available at: http://www. biodiversidad.gob.mx/especies/gran_familia/animales/ mamiferos/pdf/Mamiferos.pdf.

Ramírez Bautista A. and Hernández Ibarra X., 2004. Ficha técnica de Crotalus molossus. In: Sistemática e historia natural de algunos anfibios y reptiles de México (Arizmendi M.C., comp.). Facultad de Estudios Superiores Iztacala, Unidad de Biología, Tecnología y Prototipos (UBIPRO), Universidad Nacional Autónoma de México. Base de datos SNIB-CONABIO, proyecto W013, Mexico, $25 \mathrm{pp}$. Available at: http:// www.conabio.gob.mx/institucion/proyectos/resultados/W013_Fichas\%20de\%20Especies.pdf.

R Core Team, 2014. R: A language and environment for statistical computing. R Foundation for Statistical Computing, Vienna, Austria. Available at: http://www.R-project.org/.

Saupe E.E., Barve V., Myers C.E., Soberón J., Barve N., Hensz C.M., Peterson A.T and Lira-Noriega A., 2012. Variation in niche and distribution model performance: the need for a priori assessment of key causal factors. Ecol. Model. 237, 11-22.

DOI: 10.1016/j.ecolmodel.2012.04.001

Schloss C.A., Nuñez T.A. and Lawler J.J., 2012. Dispersal will limit ability of mammals to track climate change in the Western Hemisphere. P. Natl. Acad. Sci. USA 109, 8606-8611. DOI: 10.1073/pnas.1116791109

Sinervo B., Méndez-De-La-Cruz F., Miles D.B., Heulin B., Bastiaans E., Villagrán-Santa M., Lara-Reséndiz R., Martínez-Méndez N., Calderón-Espinosa M. L. and Meza-Lázaro R. N., 2010. Erosion of lizard diversity by climate change and altered thermal niches. Science 328, 894-899. DOI: 10.1126/science. 1184695

Soberón J. and Nakamura M., 2009. Niches and distributional areas: concepts, methods, and assumptions. P. Natl. Acad. Sci. USA 106, 19644-19650.

DOI: 10.1073 /pnas.0901637106

Thuiller W., Lafourcade B., Engler R. and Araújo M.B., 2009. BIOMOD - a platform for ensemble forecasting of species distributions. Ecography 32, 369-373.

DOI: $10.1111 / \mathrm{j} .1600-0587.2008 .05742 . x$

Wake D.B., 2007. Climate change implicated in amphibian and lizard declines. P. Natl. Acad. Sci. USA 104, 8201 8202. DOI: $10.1073 /$ pnas.0702506104

Wilson D.E. and Ruff S., 1999. The Smithsonian book of North American mammals. Smithsonian Institute, Washington, DC, 816 pp. 


\section{Appendix I}

\begin{tabular}{|c|c|}
\hline \multicolumn{2}{|c|}{ Mammals } \\
\hline Species Name & GBIF total records \\
\hline Ammospermophilus leucurus & 3112 \\
\hline Antrozous pallidus & 8532 \\
\hline Arctocephalus townsendi & 117 \\
\hline Balaenoptera edéni & 452 \\
\hline Balaenoptera acutorostrata & 11649 \\
\hline Balaenoptera musculus & 6321 \\
\hline Balaenoptera physalus & 94475 \\
\hline Bassariscus astutus & 3165 \\
\hline Canis latrans & 24842 \\
\hline Chaetodipus arenarius & 4847 \\
\hline Chaetodipus fallax & 4430 \\
\hline Chaetodipus baileyi & 7632 \\
\hline Chaetodipus intermedius & 6800 \\
\hline Chaetodipus penicillatus & 12052 \\
\hline Chaetodipus spinatus & 7286 \\
\hline Corynorhinus townsendii & 8720 \\
\hline Delphinus capensis & 922 \\
\hline Delphinus delphis & 12170 \\
\hline Dipodomys merriami & 42381 \\
\hline Eptesicus furinalis & 2286 \\
\hline Eschrichtius robustus & 5098 \\
\hline Feresa attenuata & 191 \\
\hline Globicephala macrorhynchus & 1409 \\
\hline Glossophaga soricina & 33757 \\
\hline Grampus griseus & 3766 \\
\hline Kogia sima & 573 \\
\hline Lagenorhynchus obliquidens & 1671 \\
\hline Lepus insularis & 263 \\
\hline Lasiurus cinereus & 7772 \\
\hline Lasiurus xanthinus & 610 \\
\hline Leptonycteris nivalis & 2980 \\
\hline Lepus alleni & 774 \\
\hline Lepus californicus & 9296 \\
\hline Lynx rufus & 17635 \\
\hline Macrotus californicus & 4320 \\
\hline Megaptera novaeangliae & 28654 \\
\hline Mesoplodon peruvianus & 72 \\
\hline Mirounga angustirostris & 1345 \\
\hline Mormoops megalophylla & 8109 \\
\hline Musonycteris harrisoni & 158 \\
\hline Myotis californicus & 5898 \\
\hline Myotis vivesi & 1140 \\
\hline Nasua narica & 3403 \\
\hline Neotoma albigula & 15290 \\
\hline Neotoma anthonyi & 29 \\
\hline Neotoma bryanti & 2554 \\
\hline Neotoma bunkeri & 15 \\
\hline Neotoma lepida & 11344 \\
\hline Neotoma martinensis & 8 \\
\hline
\end{tabular}




\begin{tabular}{|c|c|}
\hline \multicolumn{2}{|c|}{ Mammals } \\
\hline Species Name & GBIF total records \\
\hline Neotoma albigula & 15290 \\
\hline Notiosorex crawfordi & 1512 \\
\hline Nyctinomops femorosaccus & 1042 \\
\hline Odocoileus hemionus & 7685 \\
\hline Orcinus orca & 3090 \\
\hline Ovis canadensis & 10868 \\
\hline Peponocephala electra & 330 \\
\hline Peromyscus eremicus & 27362 \\
\hline Peromyscus eva & 1855 \\
\hline Peromyscus guardia & 173 \\
\hline Peromyscus caniceps & 95 \\
\hline Peromyscus dickeyi & 198 \\
\hline Peromyscus interparietalis & 576 \\
\hline Peromyscus maniculatus & 222.624 \\
\hline Peromyscus merriami & 1152 \\
\hline Peromyscus pembertoni & 18 \\
\hline Peromyscus pseudocrinitus & 74 \\
\hline Peromyscus sejugis & 348 \\
\hline Peromyscus slevini & 135 \\
\hline Peromyscus stephani & 121 \\
\hline Phoca vitulina & 19463 \\
\hline Pipistrellus hesperus & 7290 \\
\hline Procyon lotor & 56 \\
\hline Procyon pygmaeus & 56 \\
\hline Pseudorca crassidens & 1187 \\
\hline Reithrodontomys spectabilis & 178 \\
\hline Spermophilus tereticaudus & 2705 \\
\hline Spermophilus variegatus & 5970 \\
\hline Stenella longirostris & 2692 \\
\hline Stenella attenuata & 5639 \\
\hline Stenella coeruleoalba & 4243 \\
\hline Steno bredanensis & 863 \\
\hline Sylvilagus bachmani & 2274 \\
\hline Sylvilagus graysoni & 110 \\
\hline Sylvilagus mansuetus & 98 \\
\hline Tadarida brasiliensis & 341 \\
\hline Thomomys bottae & 39572 \\
\hline Thomomys umbrinus & 10260 \\
\hline Trichechus manatus & 1811 \\
\hline Tursiops truncatus & 30027 \\
\hline Urocyon cinereoargenteus & 9243 \\
\hline Zalophus californianus & 10314 \\
\hline Ziphius cavirostris & 1608 \\
\hline \multicolumn{2}{|c|}{ Birds } \\
\hline Species Name (2006) & GBIF total records \\
\hline Actitis macularius & 759695 \\
\hline Aimophila ruficeps & 65683 \\
\hline Amazona oratrix & 4040 \\
\hline Anas acuta & 767044 \\
\hline
\end{tabular}




\begin{tabular}{|c|c|}
\hline \multicolumn{2}{|c|}{ Birds } \\
\hline Species Name (2006) & GBIF total records \\
\hline Anas americana & 769168 \\
\hline Anas clypeata & 1222929 \\
\hline Anas crecca & 1544223 \\
\hline Anas cyanoptera & 242469 \\
\hline Anas discors & 625548 \\
\hline Anas platyrhynchos & 5321407 \\
\hline Anhinga anhinga & 263549 \\
\hline Anous minutus & 9923 \\
\hline Anous stolidus & 18121 \\
\hline Anser albifrons & 270840 \\
\hline Antrostomus badius & 286 \\
\hline Aramus guarauna & 68637 \\
\hline Aratinga brevipes & 59 \\
\hline Ardea alba & 1745615 \\
\hline Ardea herodias & 2768177 \\
\hline Arenaria interpres & 428469 \\
\hline Arenaria melanocephala & 74405 \\
\hline Aythya affinis & 576103 \\
\hline Aythya americana & 375321 \\
\hline Aythya collaris & 708914 \\
\hline Aythya valisineria & 257783 \\
\hline Bartramia longicauda & 55866 \\
\hline Bubo virginianus & 346998 \\
\hline Bubulcus ibis & 716009 \\
\hline Bucephala albeola & 1088414 \\
\hline Butorides virescens & 661885 \\
\hline Cairina moschata & 39686 \\
\hline Calidris alba & 442865 \\
\hline Calidris alpina & 785787 \\
\hline Calidris bairdii & 93011 \\
\hline Calidris canutus & 209527 \\
\hline Calidris fuscicollis & 79309 \\
\hline Calidris himantopus & 100035 \\
\hline Calidris mauri & 248957 \\
\hline Calidris melanotos & 224983 \\
\hline Calidris minutilla & 665378 \\
\hline Calidris pusilla & 299559 \\
\hline Calidris virgata & 31110 \\
\hline Cardellina pusilla & 474221 \\
\hline Cardinalis cardinalis & 4923935 \\
\hline Cathartes aura & 3037793 \\
\hline Cerorhinca monocerata & 57914 \\
\hline Charadrius semipalmatus & 406815 \\
\hline Charadrius vociferus & 2056655 \\
\hline Charadrius collaris & 11380 \\
\hline Charadrius melodus & 82045 \\
\hline Charadrius montanus & 9742 \\
\hline Charadrius nivosus & 58313 \\
\hline Charadrius semipalmatus & 406815 \\
\hline Charadrius wilsonia & 50089 \\
\hline Chen caerulescens & 269245 \\
\hline
\end{tabular}




\begin{tabular}{|c|c|}
\hline \multicolumn{2}{|c|}{ Birds } \\
\hline Species Name (2006) & GBIF total records \\
\hline Chen rossii & 58938 \\
\hline Chlidonias niger & 333686 \\
\hline Chloroceryle aenea & 7767 \\
\hline Chloroceryle americana & 53025 \\
\hline Cochlearius cochlearius & 10101 \\
\hline Colaptes auratus & 2779986 \\
\hline Columbina passerina & 199023 \\
\hline Coragyps atratus & 927262 \\
\hline Crotophaga sulcirostris & 65036 \\
\hline Cyclarhis gujanensis & 34185 \\
\hline Dendrocygna autumnalis & 154927 \\
\hline Dendrocygna bicolor & 32269 \\
\hline Diomedea immutabilis & 12068 \\
\hline Phoebastria nigripes & 28079 \\
\hline Egretta caerulea & 442000 \\
\hline Egretta rufescens & 86999 \\
\hline Egretta thula & 921359 \\
\hline Egretta tricolor & 84 \\
\hline Eudocimus albus & 417347 \\
\hline Falco peregrinus & 446209 \\
\hline Fregata magnificens & 111273 \\
\hline Fregata minor & 9664 \\
\hline Fulica americana & 1424279 \\
\hline Gallinula galeata & - \\
\hline Gavia immer & 684606 \\
\hline Geothlypis formosa & 77686 \\
\hline Glaucidium griseiceps & 702 \\
\hline Granatellus venustus & 1253 \\
\hline Grus canadensis & 407149 \\
\hline Haematopus palliatus & 156285 \\
\hline Himantopus mexicanus & 371001 \\
\hline Sterna caspia & 522584 \\
\hline Icterus cucullatus & 100503 \\
\hline Ixobrychus exilis & 58689 \\
\hline Jacana spinosa & 28789 \\
\hline Junco insularis & 418 \\
\hline Larus heermanni & 126108 \\
\hline Larus occidentalis & 345745 \\
\hline Larus californicus & 397694 \\
\hline Larus canus & 991699 \\
\hline Larus delawarensis & 2332775 \\
\hline Larus glaucescens & 339761 \\
\hline Larus heermanni & 126108 \\
\hline Larus livens & 8544 \\
\hline Larus occidentalis & 345745 \\
\hline Leucophaeus atricilla & 354283 \\
\hline Leucophaeus pipixcan & 117690 \\
\hline Limnodromus griseus & 220370 \\
\hline Limnodromus scolopaceus & 211052 \\
\hline Limosa fedoa & 184455 \\
\hline Megaceryle alcyon & 1411615 \\
\hline
\end{tabular}




\begin{tabular}{|c|c|}
\hline \multicolumn{2}{|c|}{ Birds } \\
\hline Species Name (2006) & GBIF total records \\
\hline Megascops guatemalae & 2126 \\
\hline Megascops kennicottii & 33970 \\
\hline Melanitta perspicillata & 304296 \\
\hline Melospiza lincolnii & 405446 \\
\hline Melozone fusca & 96609 \\
\hline Mergus serrator & 967918 \\
\hline Mimus graysoni & 288 \\
\hline Mycteria americana & 157568 \\
\hline Myiarchus tuberculifer & 69777 \\
\hline Numenius americanus & 135299 \\
\hline Numenius phaeopus & 343771 \\
\hline Nyctanassa violacea & 162607 \\
\hline Nycticorax nycticorax & 518518 \\
\hline Oceanodroma castro & 7891 \\
\hline Oceanodroma homochroa & 8692 \\
\hline Oceanodroma leucorrhoa & 42643 \\
\hline Oceanodroma melania & 13749 \\
\hline Oceanodroma microsoma & 3391 \\
\hline Oceanodroma homochroa & 8692 \\
\hline Oceanodroma leucorhoa & 42643 \\
\hline Oceanodroma macrodactyla & 243 \\
\hline Oceanodroma melania & 13749 \\
\hline Oceanodroma microsoma & 3391 \\
\hline Oceanodroma tethys & 2770 \\
\hline Onychoprion anaethetus & 13974 \\
\hline Onychoprion fuscatus & 25889 \\
\hline Leiothlypis celata & 605714 \\
\hline Leiothlypis peregrina & 274762 \\
\hline Leiothlypis ruficapilla & 382102 \\
\hline Oxyura jamaicensis & 712019 \\
\hline Pandion haliaetus & 1260662 \\
\hline Parkesia motacilla & 131963 \\
\hline Parkesia noveboracensis & 272477 \\
\hline Parula pitiayumi & 2598 \\
\hline Passer domesticus & 4253591 \\
\hline Passerina caerulea & 258187 \\
\hline Patagioenas flavirostris & 35987 \\
\hline Pelecanus erythrorhynchos & 408913 \\
\hline Pelecanus occidentalis & 549569 \\
\hline Phaethon aethereus & 7070 \\
\hline Phalacrocorax auritus & 2011586 \\
\hline Phalacrocorax penicillatus & 115117 \\
\hline Phalacrocorax auritus & 2011586 \\
\hline Phalacrocorax brasilianus & 206314 \\
\hline Phalacrocorax pelagicus & 138217 \\
\hline Phalacrocorax penicillatus & 115117 \\
\hline Phalaropus fulicarius & 47854 \\
\hline Phalaropus lobatus & 142692 \\
\hline Phalaropus tricolor & 138837 \\
\hline Pheugopedius felix & 8225 \\
\hline Phoebastria albatrus & 2337 \\
\hline
\end{tabular}




\begin{tabular}{|c|c|}
\hline \multicolumn{2}{|c|}{ Birds } \\
\hline Species Name (2006) & GBIF total records \\
\hline Phoebastria immutabilis & 12068 \\
\hline Phoebastria nigripes & 28079 \\
\hline Phoenicopterus ruber & 30077 \\
\hline Piranga bidentata & 10977 \\
\hline Platalea ajaja & 142663 \\
\hline Pluvialis dominica & 77650 \\
\hline Pluvialis fulva & 66867 \\
\hline Pluvialis squatarola & 588384 \\
\hline Podiceps nigricollis & 296386 \\
\hline Podilymbus podiceps & 1151778 \\
\hline Caracara lutosa & 8 \\
\hline Porphyrio martinica & 56656 \\
\hline Porzana carolina & 210564 \\
\hline Pterodroma cookii & 1617 \\
\hline Pterodroma neglecta & 827 \\
\hline Pterodroma phaeopygia & 7385 \\
\hline Ptychoramphus aleuticus & 40503 \\
\hline Ptychoramphus aleuticus & 40503 \\
\hline Puffinus auricularis & 281 \\
\hline Puffinus opisthomelas & 20441 \\
\hline Puffinus creatopus & 40015 \\
\hline Puffinus griseus & 108817 \\
\hline Puffinus opisthomelas & 20441 \\
\hline Puffinus pacificus & 82635 \\
\hline Puffinus tenuirostris & 135042 \\
\hline Rallus limicola & 147749 \\
\hline Recurvirostra americana & 272007 \\
\hline Rissa tridactyla & 194066 \\
\hline Rynchops niger & 142333 \\
\hline Setophaga americana & 506144 \\
\hline Setophaga castanea & 107360 \\
\hline Setophaga cerulea & 53571 \\
\hline Setophaga citrina & 184752 \\
\hline Setophaga coronata & 2350719 \\
\hline Setophaga discolor & 190158 \\
\hline Setophaga dominica & 178863 \\
\hline Setophaga fusca & 206037 \\
\hline Setophaga magnolia & 396048 \\
\hline Setophaga nigrescens & 126652 \\
\hline Setophaga palmarum & 527292 \\
\hline Setophaga pensylvanica & 355131 \\
\hline Setophaga petechia & 1212597 \\
\hline Setophaga pitiayumi & 35953 \\
\hline Setophaga striata & 231487 \\
\hline Setophaga tigrina & 108848 \\
\hline Setophaga townsendi & 202054 \\
\hline Setophaga virens & 429440 \\
\hline Sphyrapicus varius & 528884 \\
\hline Spinus psaltria & 696736 \\
\hline Spiza americana & 136864 \\
\hline Stelgedopteryx serripennis & 659369 \\
\hline
\end{tabular}




\begin{tabular}{|c|c|}
\hline \multicolumn{2}{|c|}{ Birds } \\
\hline Species Name (2006) & GBIF total records \\
\hline Stercorarius pomarinus & 62305 \\
\hline Sterna anaethetus & 13974 \\
\hline Sterna elegans & 62405 \\
\hline Sterna fuscata & - \\
\hline Sterna maxima & 272830 \\
\hline Sterna forsteri & 429478 \\
\hline Sterna hirundo & 646877 \\
\hline Sternula antillarum & 161999 \\
\hline Sula granti & 3087 \\
\hline Sula leucogaster & 39534 \\
\hline Sula nebouxii & 14032 \\
\hline Sula sula & 9915 \\
\hline Sula dactylatra & 9071 \\
\hline Sula leucogaster & 39534 \\
\hline Sula nebouxii & 14032 \\
\hline Synthliboramphus hypoleucus & 7130 \\
\hline Synthliboramphus craveri & 1678 \\
\hline Synthliboramphus hypoleucus & 7130 \\
\hline Synthliboramphus scrippsi & 4675 \\
\hline Sterna elegans & 62405 \\
\hline Thalasseus maximus & 272832 \\
\hline Sterna sandvicensis & 237695 \\
\hline Tigrisoma mexicanum & 14954 \\
\hline Toxostoma guttatum & 236 \\
\hline Tringa flavipes & 493255 \\
\hline Heteroscelus incana & 34372 \\
\hline Tringa melanoleuca & 717942 \\
\hline Tringa semipalmata & 470248 \\
\hline Tringa solitaria & 247133 \\
\hline Troglodytes tanneri & 227 \\
\hline Troglodytes sissonii & 379 \\
\hline Vermivora chrysoptera & 52440 \\
\hline Vermivora cyanoptera & 136467 \\
\hline Vireo flavoviridis & 13908 \\
\hline Xema sabini & 29919 \\
\hline Zenaida aurita & 28124 \\
\hline Zenaida graysoni & 207 \\
\hline \multicolumn{2}{|c|}{ Reptiles } \\
\hline Species Name (CAT, 2013) & GBIF total records \\
\hline Agkistrodon bilineatus & 534 \\
\hline Anniella geronimensis & 380 \\
\hline Anniella pulchra & 3451 \\
\hline Anolis nebulosus & 4011 \\
\hline Aspidoscelis ceralbensis & 378 \\
\hline Aspidoscelis hyperythra & 4471 \\
\hline Aspidoscelis tigris & 31679 \\
\hline Aspidoscelis communis & 1776 \\
\hline Aspidoscelis cozumela & 481 \\
\hline Aspidoscelis guttata & 2511 \\
\hline
\end{tabular}




\begin{tabular}{|c|c|}
\hline \multicolumn{2}{|c|}{ Reptiles } \\
\hline Species Name (CAT, 2013) & GBIF total records \\
\hline Aspidoscelis rodecki & 156 \\
\hline Gopherus agassizii & 3123 \\
\hline Masticophis mentovarius & 1585 \\
\hline Bipes biporus & 3074 \\
\hline Boa constrictor & 5790 \\
\hline Bogertophis rosaliae & 47 \\
\hline Callisaurus draconoides & 23722 \\
\hline Callisaurus draconoides & 24128 \\
\hline Caretta caretta & 26736 \\
\hline Charina trivirgata & 386 \\
\hline Chelonia mydas & 20487 \\
\hline Chilomeniscus stramineus & 1021 \\
\hline Chilomeniscus savagei & 17 \\
\hline Aspidoscelis bacatus & - \\
\hline Aspidoscelis canus & - \\
\hline Aspidoscelis carmenensis & - \\
\hline Aspidoscelis catalinensis & - \\
\hline Aspidoscelis ceralbensis & 378 \\
\hline Aspidoscelis costata & 3428 \\
\hline Aspidoscelis gularis & 10691 \\
\hline Aspidoscelis hyperythra & 4471 \\
\hline Aspidoscelis communis & 1776 \\
\hline Aspidoscelis martyris & - \\
\hline Aspidoscelis estebanensis & - \\
\hline Coleonyx gypsicolus & - \\
\hline Coleonyx variegatus & 6561 \\
\hline Crocodylus moreletii & 3665 \\
\hline Crotalus mitchellii & 475292 \\
\hline Crotalus atrox & 9861 \\
\hline Crotalus oreganus & 6530 \\
\hline Crotalus catalinensis & 61 \\
\hline Crotalus cerastes & 4385 \\
\hline Crotalus enyo & 538 \\
\hline Crotalus estebanensis & - \\
\hline Crotalus stephensi & 475305 \\
\hline Crotalus ruber & 2623 \\
\hline Crotalus tigris & 546 \\
\hline Crotalus atrox & 9861 \\
\hline Crotaphytus dickersonae & 284 \\
\hline Ctenosaura nolascensis & - \\
\hline Ctenosaura acanthura & 822 \\
\hline Ctenosaura pectinata & 2871 \\
\hline Ctenosaura similis & 4174 \\
\hline Dermochelys coriacea & 4433 \\
\hline Diadophis punctatus & 19121 \\
\hline Leptophis diplotropis & 741 \\
\hline Dipsosaurus dorsalis & 7838 \\
\hline Mastigodryas melanolomus & 2446 \\
\hline Elgaria cedrosensis & 26 \\
\hline Elgaria multicarinata & 8662 \\
\hline Elgaria nana & - \\
\hline
\end{tabular}




\begin{tabular}{|c|c|}
\hline \multicolumn{2}{|c|}{ Reptiles } \\
\hline Species Name (CAT, 2013) & GBIF total records \\
\hline Eretmochelys imbricata & 4774 \\
\hline Eridiphas slevini & - \\
\hline Gambelia copeii & 189 \\
\hline Gambelia wislizenii & 4864 \\
\hline Hypsiglena chlorophaea & 391 \\
\hline Kinosternon integrum & 4112 \\
\hline Lampropeltis catalinensis & - \\
\hline Lampropeltis herrerae & - \\
\hline Lampropeltis zonata & 777 \\
\hline Lepidochelys olivacea & 5910 \\
\hline Leptophis diplotropis & 741 \\
\hline Rena humilis & 753 \\
\hline Masticophis aurigulus & 29 \\
\hline Masticophis bilineatus & 16 \\
\hline Masticophis flagellum & 1313 \\
\hline Coluber fuliginosus & 355 \\
\hline Masticophis slevini & 6 \\
\hline Mastigodryas melanolomus & 1872 \\
\hline Micruroides euryxanthus & 555 \\
\hline Oxybelis aeneus & 4599 \\
\hline Pelamis platurus & 1262 \\
\hline Petrosaurus repens & 116 \\
\hline Petrosaurus slevini & - \\
\hline Petrosaurus thalassinus & 1010 \\
\hline Phrynosoma coronatum & 4182 \\
\hline Phrynosoma solare & 1674 \\
\hline Phyllodactylus nocticolus & 307 \\
\hline Phyllodactylus bugastrolepis & 94 \\
\hline Phyllodactylus homolepidurus & 366 \\
\hline Phyllodactylus partidus & 51 \\
\hline Phyllodactylus unctus & 742 \\
\hline Phyllodactylus xanti & 1400 \\
\hline Phyllodactylus tuberculosus & 2405 \\
\hline Phyllorhynchus decurtatus & 2877 \\
\hline Pituophis catenifer & 15394 \\
\hline Pituophis insulanus & - \\
\hline Pituophis vertebralis & 55 \\
\hline Rhinocheilus etheridgei & - \\
\hline Salvadora hexalepis & 2431 \\
\hline Sceloporus angustus & 625 \\
\hline Sceloporus grandaevus & 1050 \\
\hline Sauromalus hispidus & 379 \\
\hline Sauromalus ater & 2726 \\
\hline Sauromalus slevini & 50 \\
\hline Sauromalus varius & 325 \\
\hline Sceloporus clarckii & 6843 \\
\hline Sceloporus hunsakeri & 916 \\
\hline Sceloporus lineatulus & 15 \\
\hline Sceloporus occidentalis & 32209 \\
\hline Sceloporus orcutti & 2804 \\
\hline Sceloporus zosteromus & 928 \\
\hline
\end{tabular}




\begin{tabular}{|c|c|}
\hline \multicolumn{2}{|l|}{ Reptiles } \\
\hline Species Name (CAT, 2013) & GBIF total records \\
\hline Sceloporus smithi & 160 \\
\hline Sceloporus variabilis & 16407 \\
\hline Sibon nebulatus & 1448 \\
\hline Sonora semiannulata & 7124 \\
\hline Tantilla planiceps & 387 \\
\hline Trimorphodon biscutatus & 2389 \\
\hline Urosaurus nigricaudus & 4514 \\
\hline Urosaurus ornatus & 20571 \\
\hline Uta nolascensis & 118 \\
\hline Uta palmeri & 733 \\
\hline Uta squamata & 312 \\
\hline Uta stansburiana & 59717 \\
\hline \multicolumn{2}{|l|}{ Amphibians } \\
\hline Species Name (2011) & GBIF total records \\
\hline Anaxyrus cognatus (Bufo cognatus) & 11315 \\
\hline Anaxyrus californicus (Bufo californicus) & 1574 \\
\hline Anaxyrus punctatus (Bufo punctatus) & 13143 \\
\hline Anaxyrus woodhousii (Bufo woodhousii) & 21016 \\
\hline Aneides lugubris & 5998 \\
\hline Batrachoseps major & 5096 \\
\hline Anaxyrus punctatus (Bufo punctatus) & 13143 \\
\hline Incilius alvarius & 2197 \\
\hline Anaxyrus boreas & 19304 \\
\hline Ensatina eschscholtzii & 18034 \\
\hline Pseudacris regilla & 25399 \\
\hline Hypopachus variolosus & 4752 \\
\hline Incilius alvarius & 2197 \\
\hline Leptodactylus fragilis & 2289 \\
\hline Leptodactylus melanonotus & 12435 \\
\hline Lithobates berlandieri & 15354 \\
\hline Lithobates catesbeianus & 28829 \\
\hline Lithobates forreri & 3085 \\
\hline Lithobates yavapaiensis & 2388 \\
\hline Pseudacris regilla & 25399 \\
\hline Lithobates berlandieri & 15354 \\
\hline Lithobates catesbeianus & 28829 \\
\hline Lithobates forreri & 3085 \\
\hline Lithobates yavapaiensis & 2388 \\
\hline Scaphiopus couchii & 12425 \\
\hline Smilisca baudinii & 16555 \\
\hline Spea hammondii & 4847 \\
\hline
\end{tabular}




\section{Appendix II}

Area loss, gains and net change for all species evaluated. Total number of pixels: number of pixels in Mexico at $1 \mathrm{~km}^{2}$ resolution. \#Unique data: number of unique georreferenced data in a $1 \mathrm{~km}^{2}$ resolution cell. \#Pixels: number of pixels in which de species is present. \%Loss: geographic area that was climatically suitable under current conditions and will not be suitable in the future. \%Gains: geographic area that was not suitable under current climatic conditions but will be climatically suitable in the future. Net change: difference between \%gains and \%loss. Short term: 2015-2039. Long term: 2075-2099. 


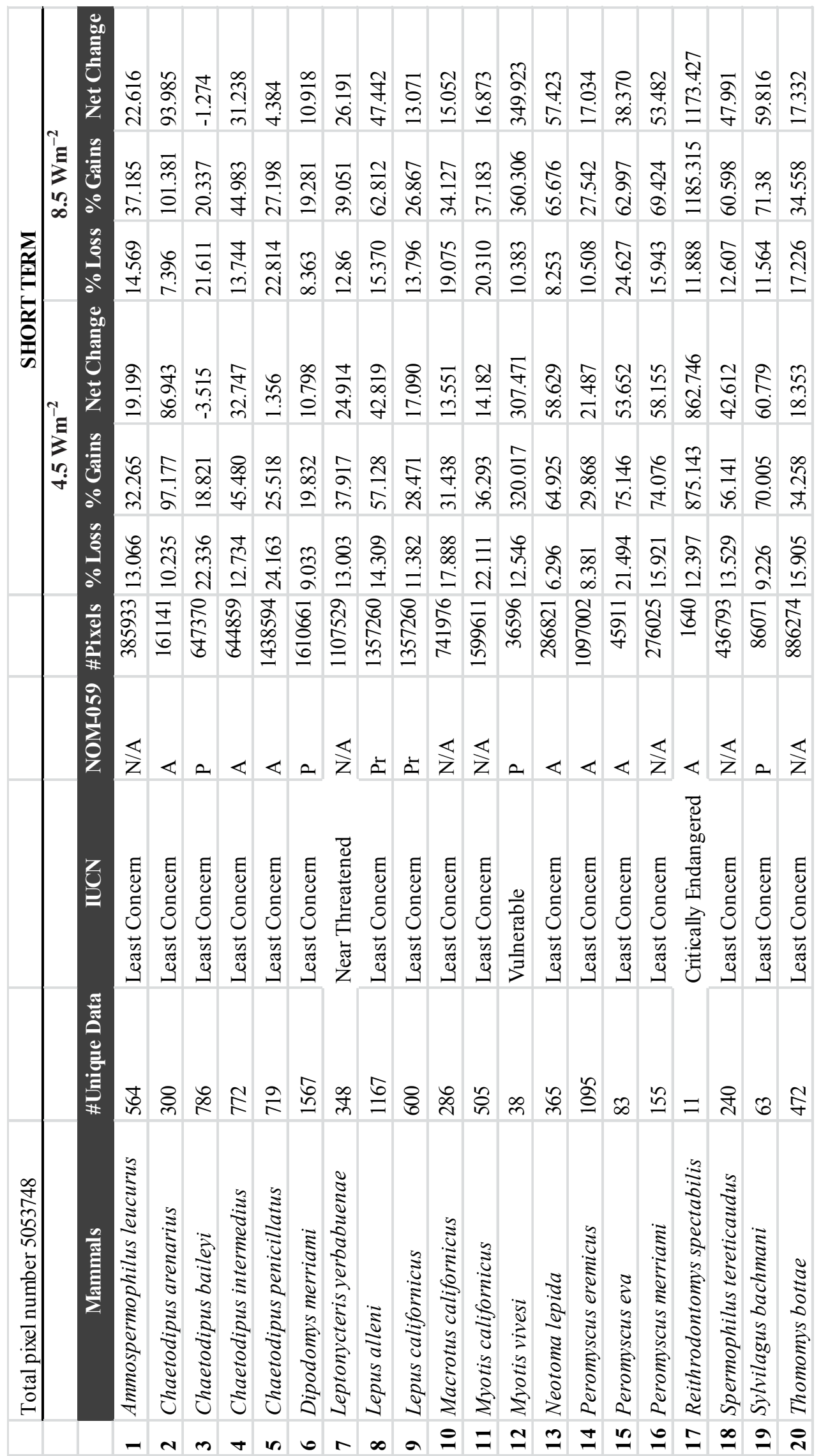




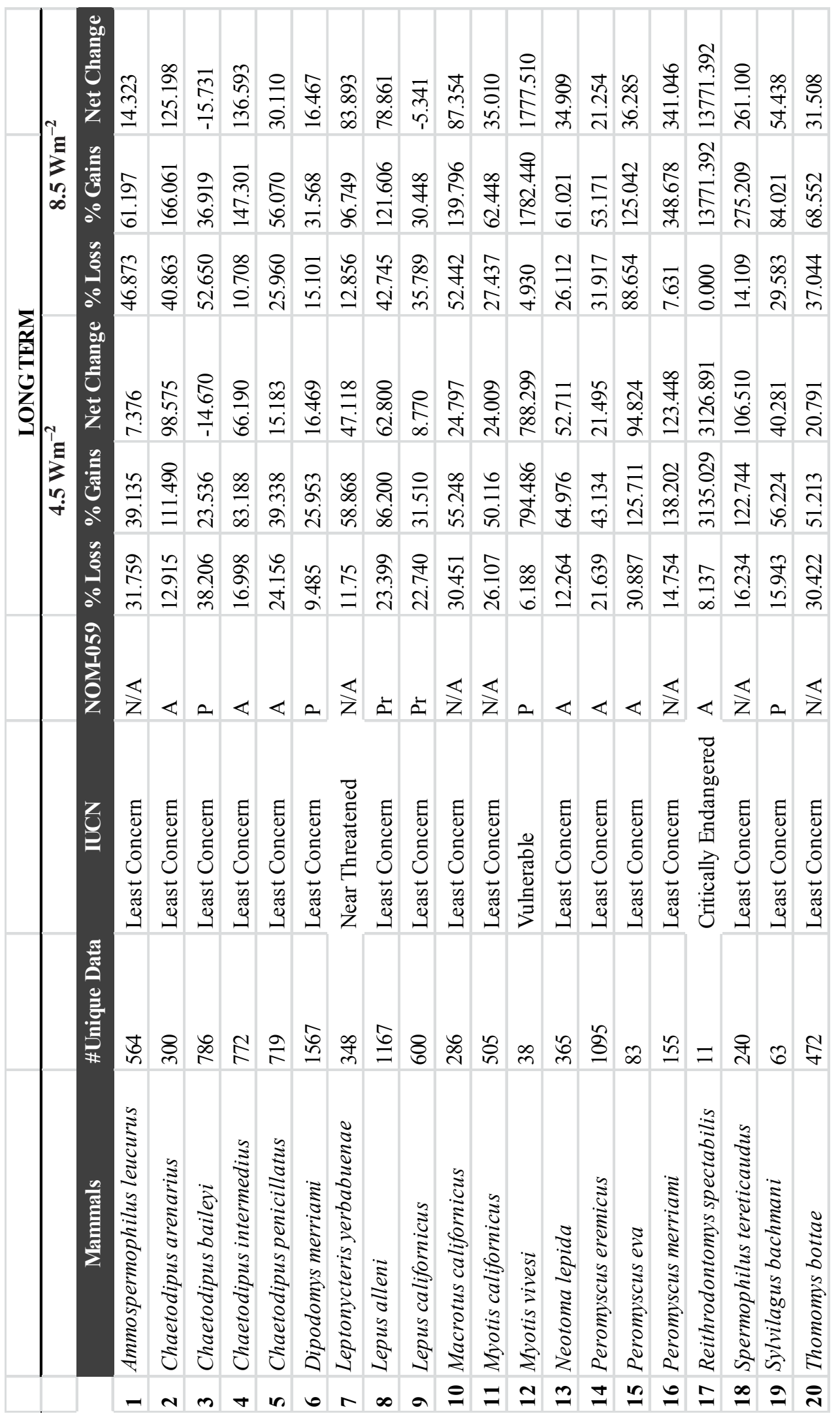




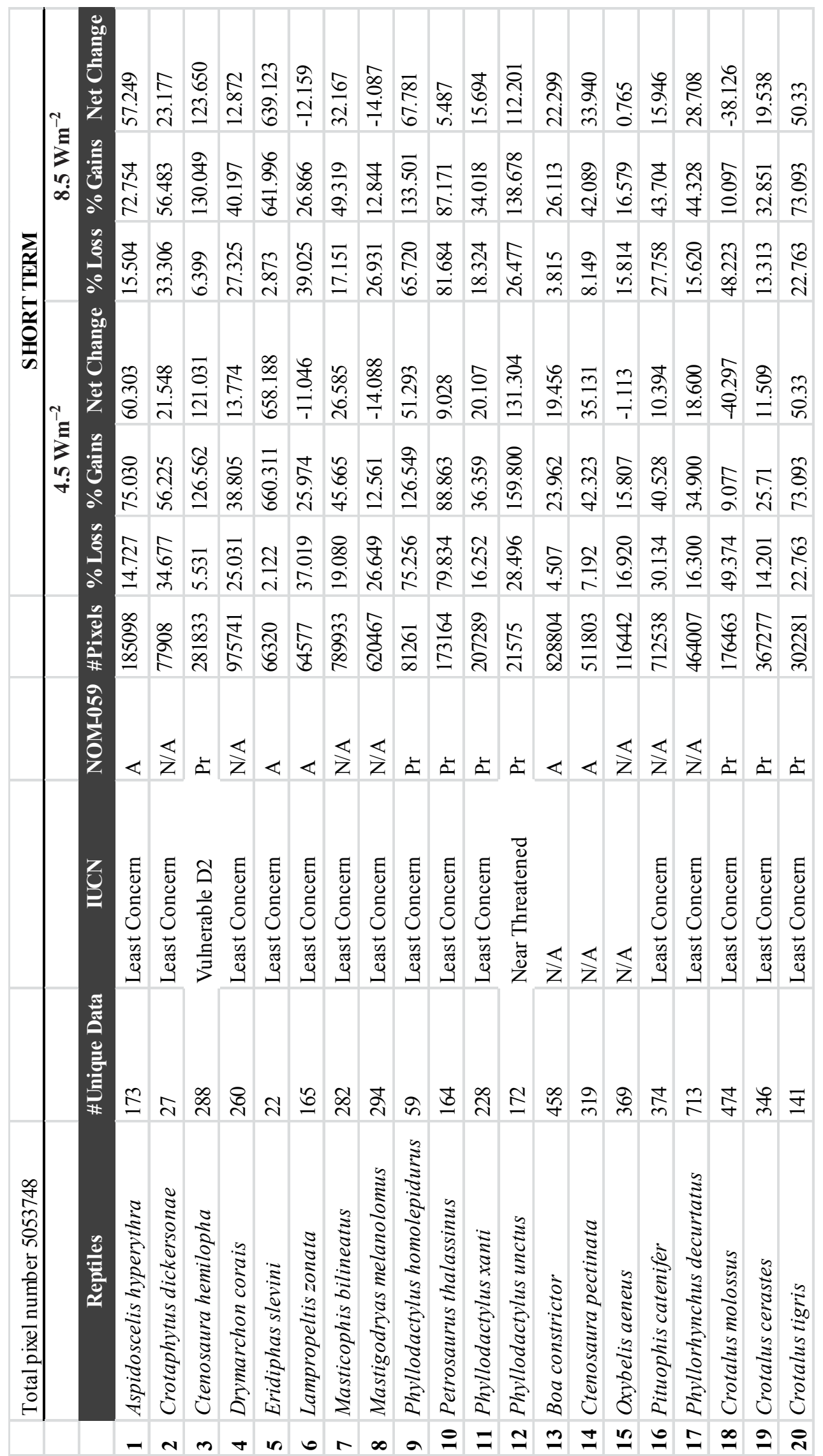




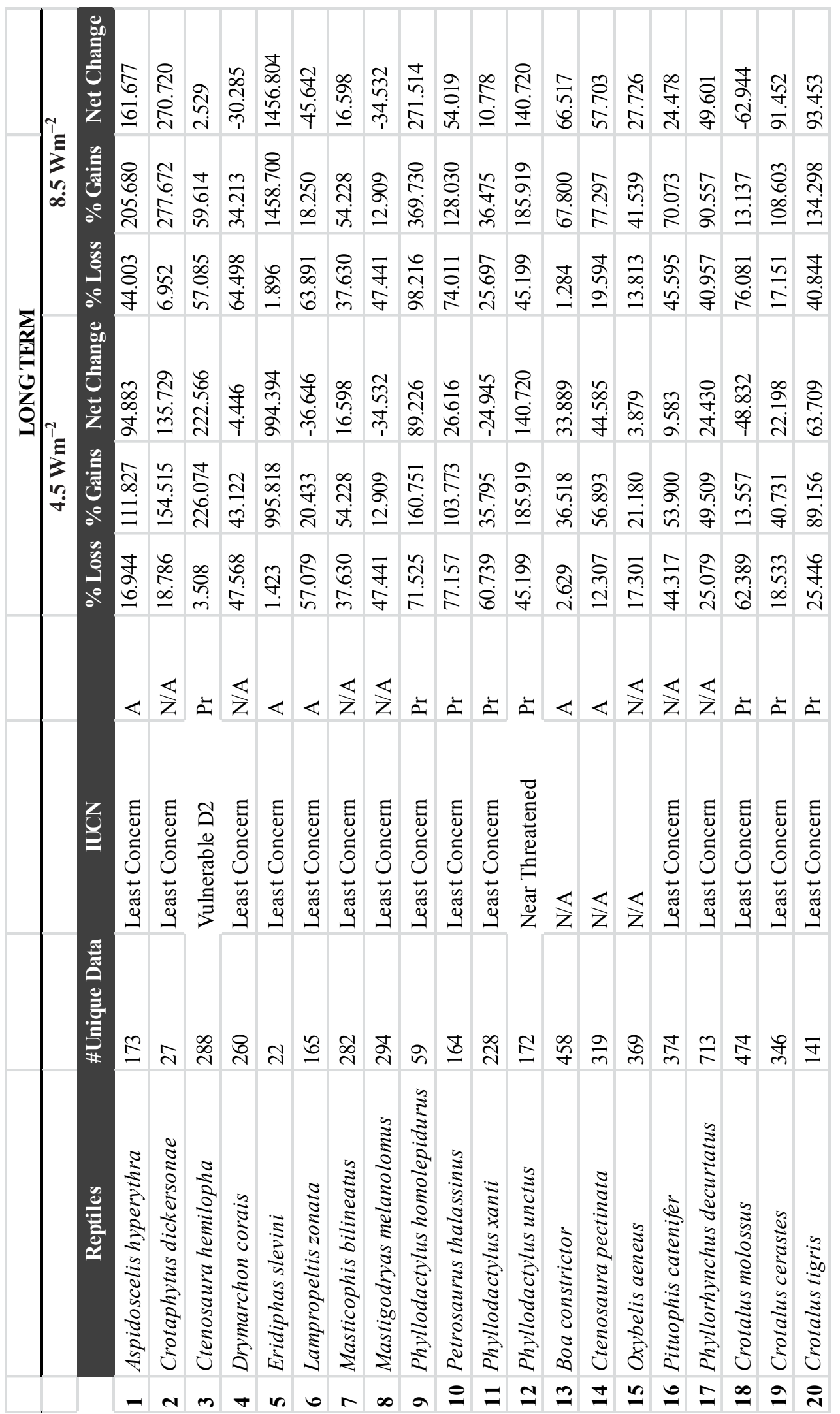




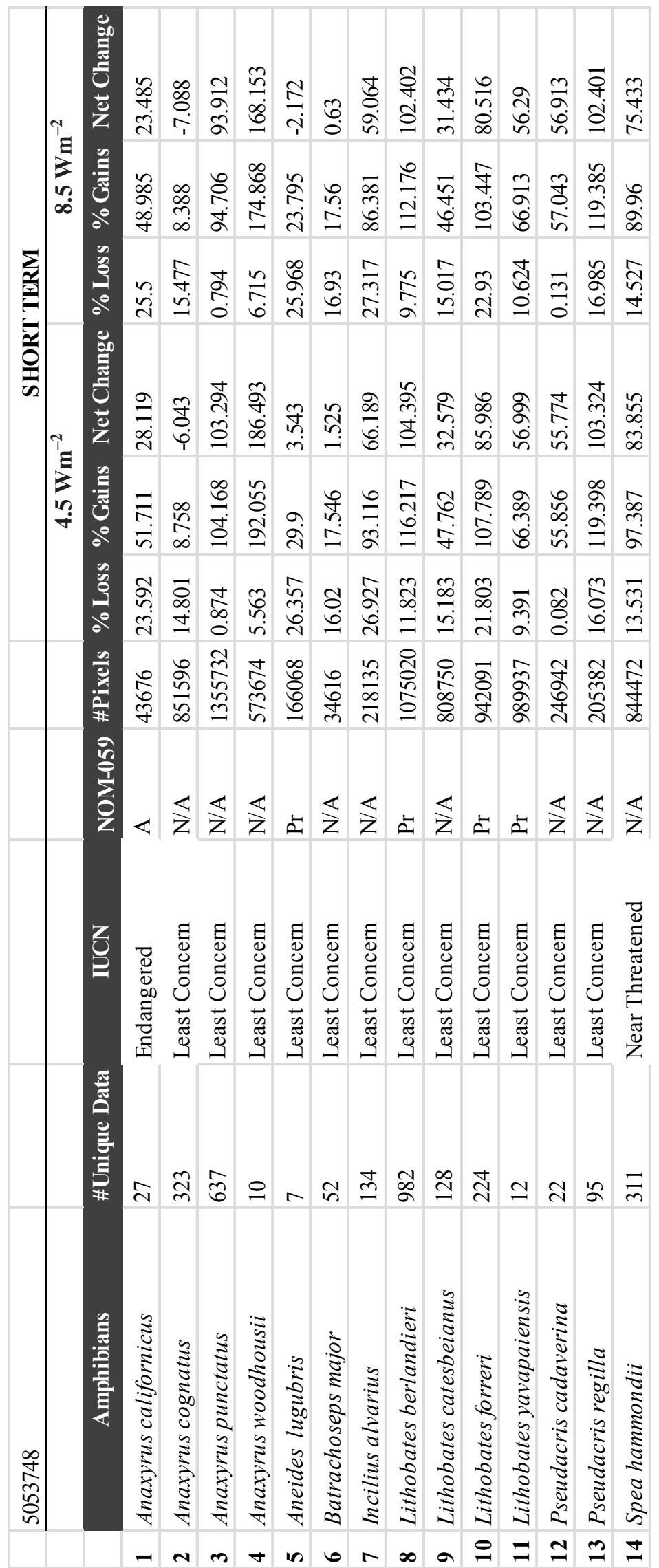




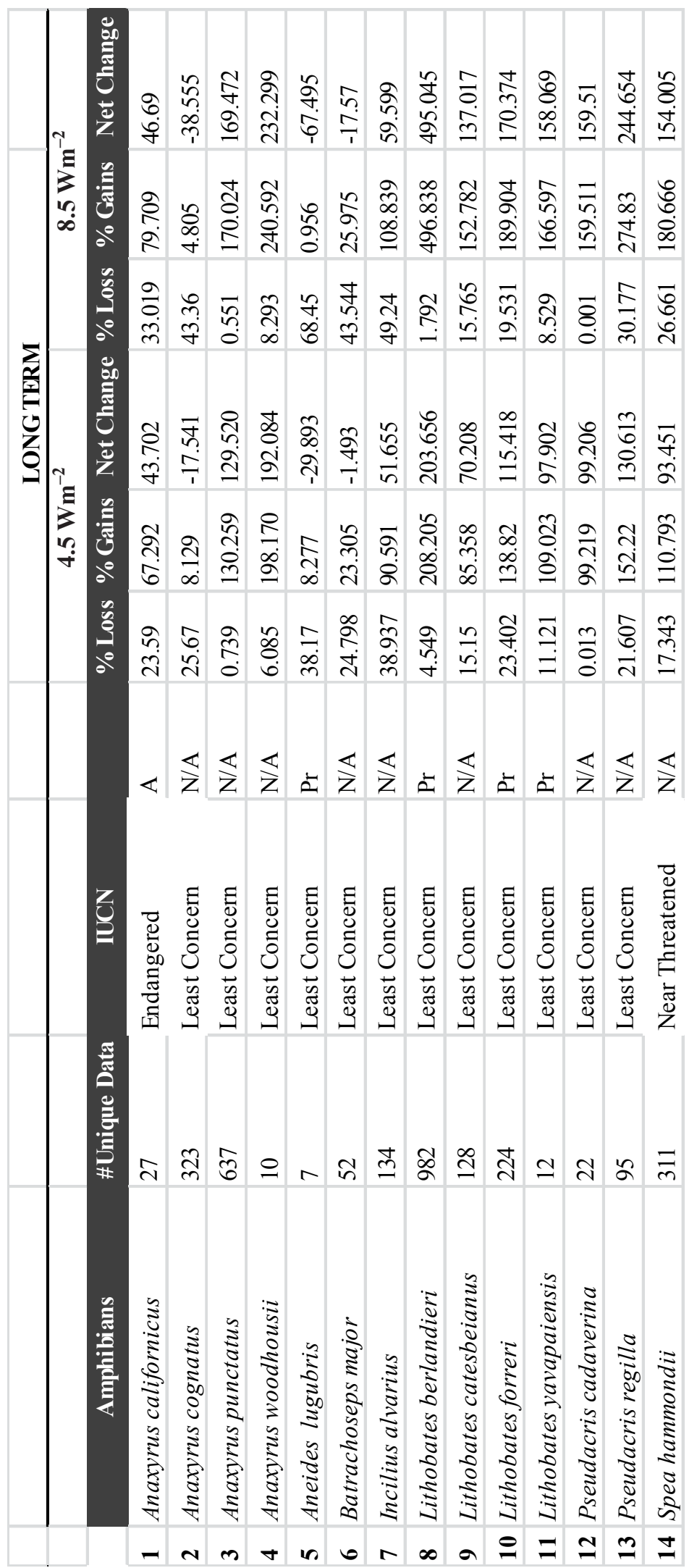





\section{Appendix III}

Species' richness maps. (a) Mammals, (b) reptiles, (c) amphibians. Richness maps are shown under present climatic conditions and under two time series (2015-2039 and 2075-2099). Under future climatic conditions species were projected under two different RCPs $\left(\mathrm{Wm}^{-2}\right)$ (representative concentration pathways).

(a) Mammals

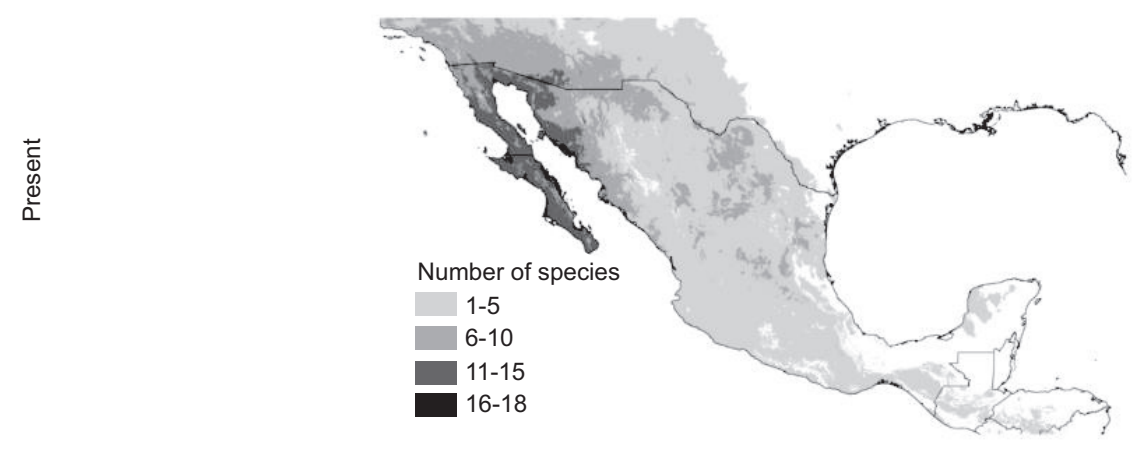

RCP 4.5
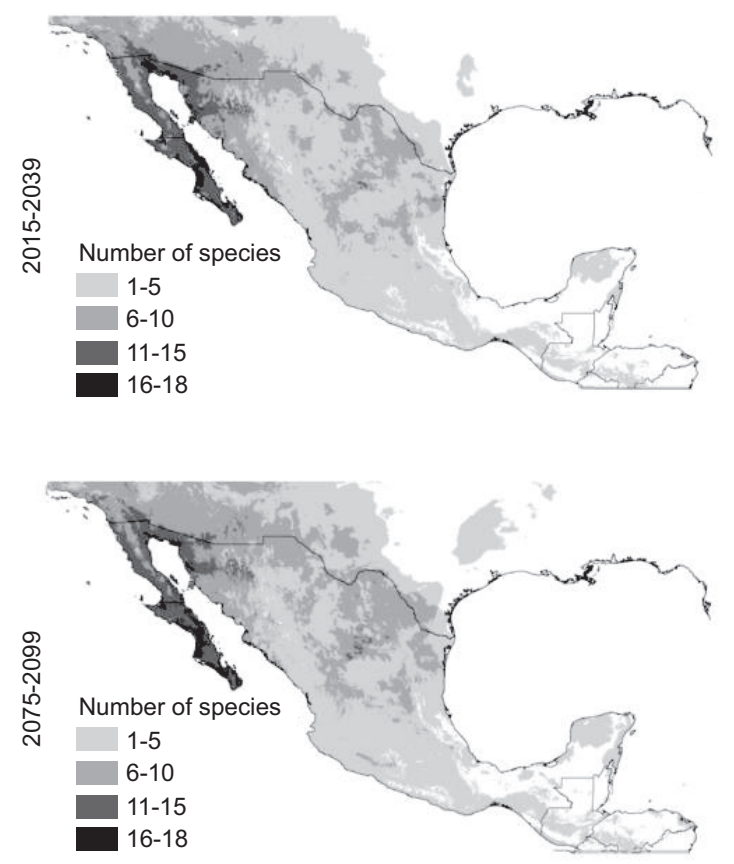

RCP 8.5
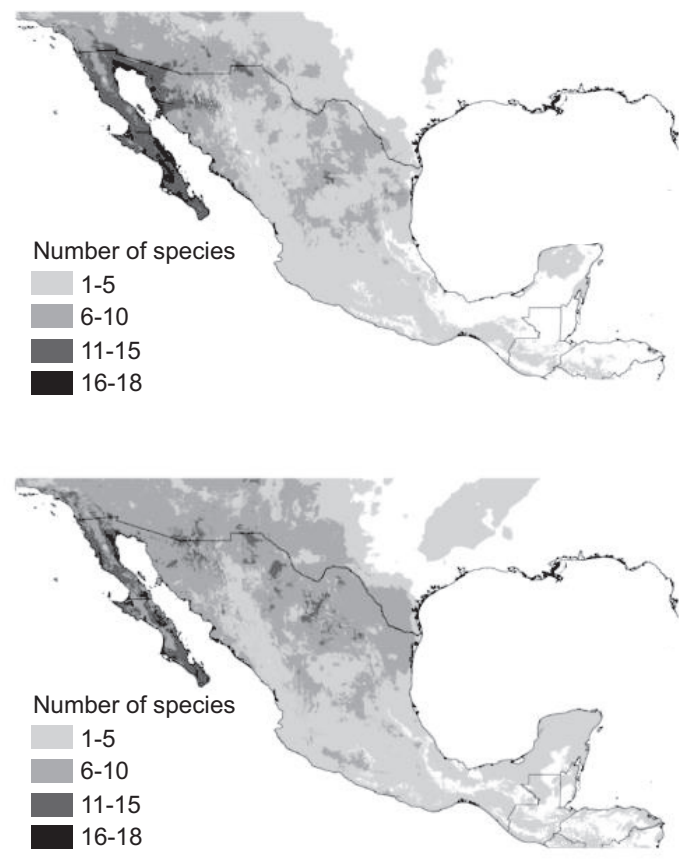
(b) Reptiles

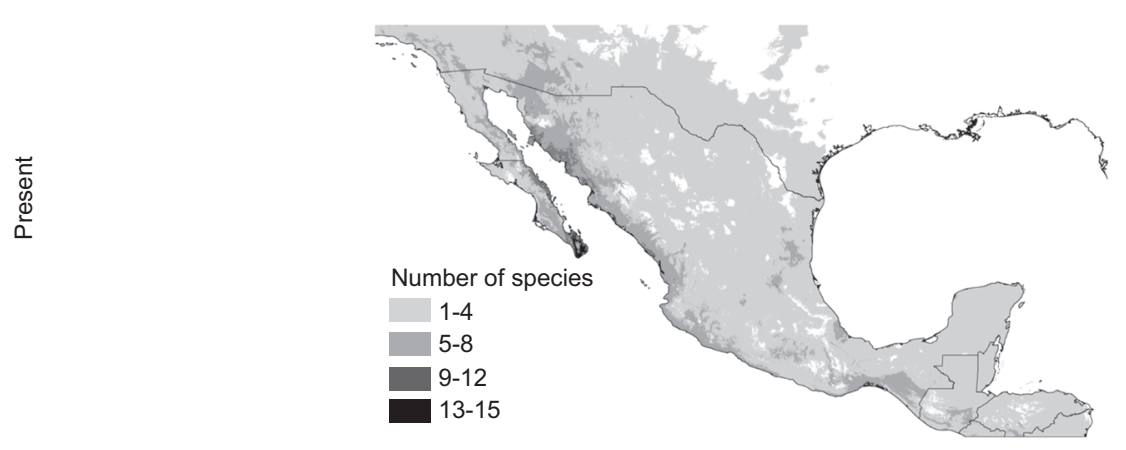

RCP 4.5
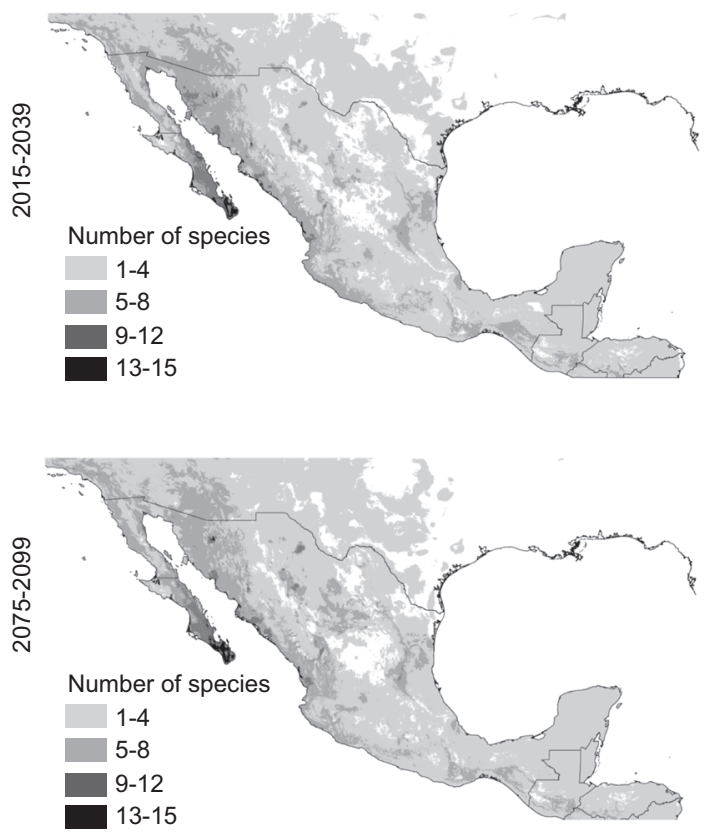

RCP 8.5
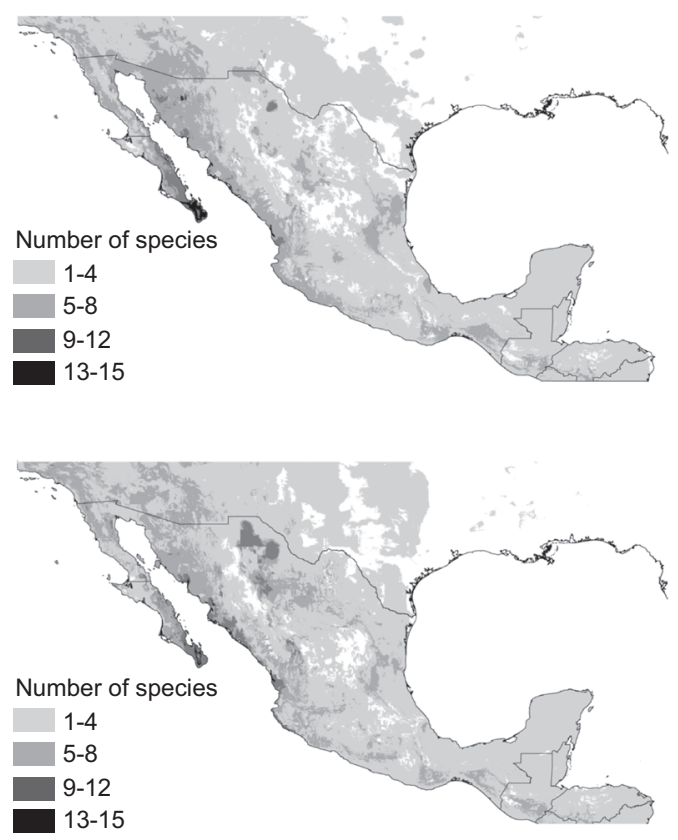
(c) Amphibians
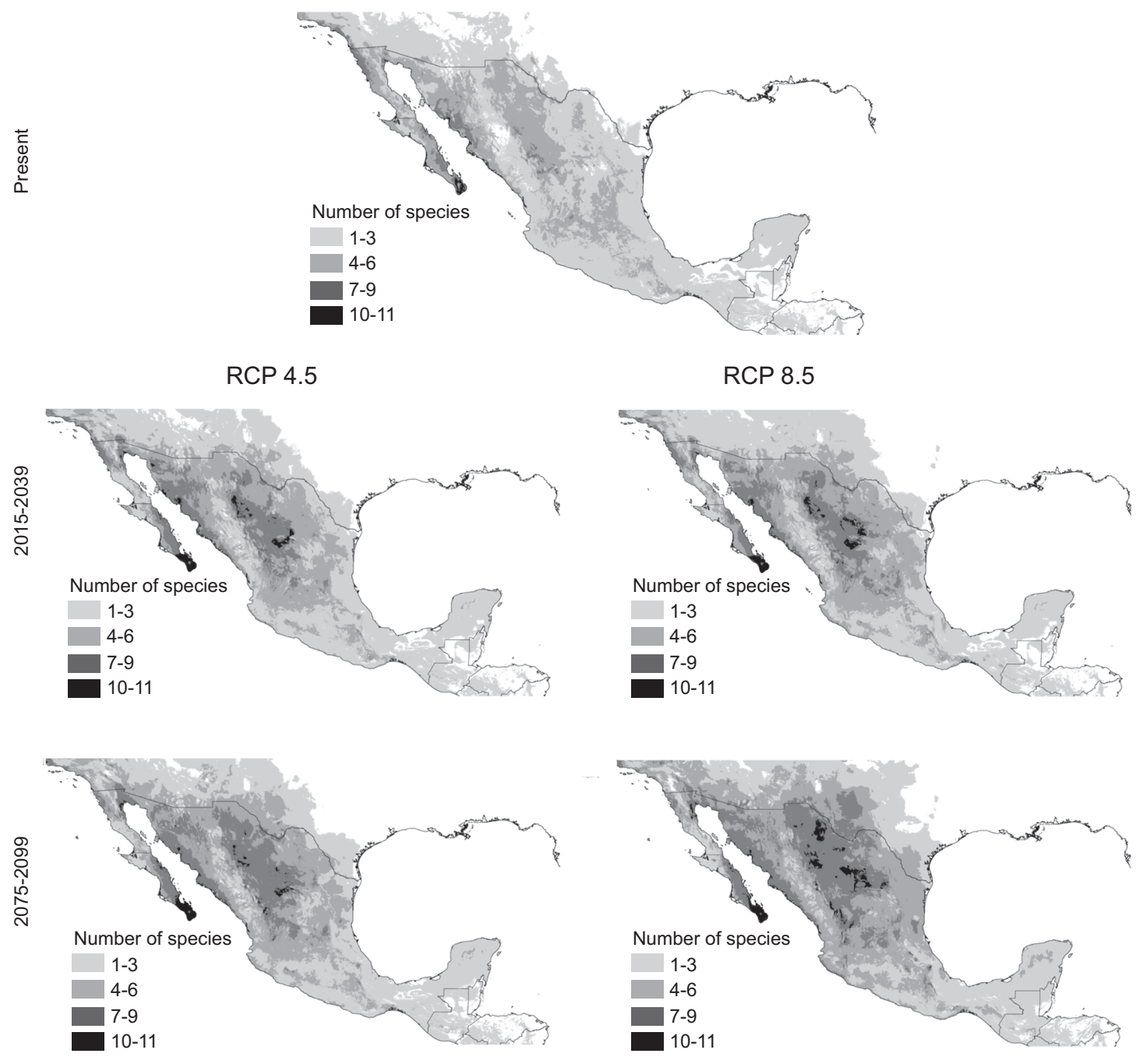